\title{
Astrofood, Priorities and Pandemics: Reflections of an Ultra-Processed Breakfast Program and Contemporary Dysbiotic Drift
}

\author{
Alan C. Logan 1,* (iD) and Susan L. Prescott ${ }^{1,2}$ \\ 1 FLAME Global Network, Research Group of the Worldwide Universities Network (WUN), 6010 Park Ave, \\ Suite \#4081, West New York, NJ 07093, USA; susan.prescott@uwa.edu.au \\ 2 Paediatrics, School of Medicine, University of Western Australia, P.O. Box D184, Princess Margaret Hospital, \\ Perth, WA 6001, Australia \\ * Correspondence: aclnd@cfs-fm.org
}

Received: 22 August 2017; Accepted: 6 September 2017; Published: 7 September 2017

\begin{abstract}
Recognizing the importance of nutrition as part of the grand challenges faced by humanity-the current epidemic of non-communicable diseases (NCDs), sustainability and maintenance of Planetary Health — the United Nations (UN) has declared 2016-2025 the Decade of Nutrition. Research continues to underscore the extent to which ultra-processed foods dominate the contemporary nutritional landscape. Moreover, the dual role played by food technology and marketing in the expansion of ultra-processed foods is under increased scrutiny. As public health experts and clinicians contend with a crisis of NCDs, attempting to untangle a knotted assortment of interrelated strands of causation, an examination of the early origins of highly-marketed ultra-processed foods can provide valuable lessons. Here, we illuminate a little-known piece of history in the annals of ultra-processed nutritional science and childhood welfare. Astrofood was a commercially-marketed, collaborative government-industry effort that brought soy protein-enriched Twinkies as a nutritive breakfast cake to disadvantaged children; its concept and delivery demonstrated an unwillingness to deal with root-cause challenges. Although its official tenure was only about 7 years, we argue that Astrofood and its total food engineering still resonate throughout the global ultra-processed nutritional landscape. New scientific advances in nutritional psychiatry and the microbiome are on a collision course with the profits, marketing and intellectual dishonesty of the ultra-processed food industry. Solutions to the grand challenges of the Decade of Nutrition may be found in lessons from Astrofood. They provide clues to undoing the tangled knots which otherwise maintain an untenable status quo.
\end{abstract}

Keywords: anthropocene; societies; social justice; ecology; microbiome; prevention; health policy; equity; mental health; non-communicable diseases; lifestyle medicine; nutrition

\section{Introduction}

"We achieve what nature could not do." Robert H. Cotton, International Telephone and Telegraph Corporation [1].

In the spring of 1971, 12,000 financially disadvantaged American children in schools and day care centres were provided with a unique, federally-funded breakfast cake. Its manufacturer, the mega-multinational International Telephone and Telegraph Corporation (ITT) and its subsidiary Continental Baking Company, touted the breakfast cake as a breakthrough in food engineering. In a nationwide marketing campaign, ITT claimed (as it did to Congress) that when combined with milk, the fortified cake-known as Astrofood-was the nutritional equivalent of "four ounces of orange juice, two strips of bacon, an egg, and a piece of buttered toast" [2]. The following year ITT was churning out 
more than half-a-million Astrofood cakes per month, and by 1974-at the cajoling of ITT and over the objection of select nutrition advocates-the inclusion of fortified, ultra-processed cakes became a formal part of the United States Department of Agriculture (USDA) Federal School Breakfast Program [3].

The Astrofood concept was a collaboration between ITT's Vice President at Continental Bakery, Robert H. Cotton, and USDA Deputy Director Ed Koenig. In his own words, Koenig describes the origins in clear terms: "We wanted to devise a food that was cheap and easy to handle. We got a brainstorm. ITT's biggest seller with kids is Hostess Twinkies. We figured if we make something as appealing as a Twinkie, yet as nutritious as fruit and cereal...we needed something fast and ITT had a product that was ready to go" [4]. Furthermore, Koenig also described the ease with which the brainstorm could be put into action: "A truck can back up to the school door, dump hundreds of cartons of milk and cakes in the hallway if need be, the kids can grab them and eat them. No forks or spoons, none of this bowls or glasses of juice spilling over" [5]. With a tweak of the USDA language concerning the definition of breakfast, the idea moved forward; Food and Nutrition Service, Child Nutrition Notice 180 of 19 October 1970, included a "Fortified Cake Product with Creamed Filling for Use in Breakfasts" [6].

In its nationwide marketing campaign, with dominant ads in media outlets ranging from the Los Angeles Times to Ebony and Black Enterprise, ITT told a more nuanced story of the intellectual wellspring for Astrofood [7-9]. They claimed the product was in response to the challenges set forth at the White House Conference on Food, Nutrition and Health which was held 2-4 December 1969. Attended by some 3000 interested parties from science, medicine, academia and industry, the White House Conference focused on, among other subjects, the prevalence of childhood hunger in the US. The conference included several "New Food" panels geared toward food engineering and assembling novel dietary items from isolated macro/micro nutrients, both natural and synthetic. The conclusion of the corporate-led panel was immediate food fortification program to relieve malnutrition. Robert $\mathrm{H}$. Cotton of ITT was on the panel devoted to systems of delivery for food, which recommended "research on new foods, especially nutritional snacks, which could be introduced through the schools but which might have an impact on the whole population" [10].

\subsection{Roadmap to the Current Review}

Here in our perspective review, we will discuss the nutritional formulation of Astrofood and place its historical development and continued legacy in the contemporary context of a nutritional landscape dominated by highly-processed foods, corporate-public health campaigns intertwined with profits, and an epidemic of non-communicable diseases (NCDs). We argue that Astrofood, once brought to disadvantaged American schoolchildren by the makers of Twinkies, is a symbol of modern-day dysbiotic drift; from its Greek root, dysbiosis translates as "life in distress". The term is also used in the microbial context where it is defined by loss of beneficial microorganisms, and/or the expansion of potentially harmful microbes, and/or the loss of overall microbial diversity. We will underscore the ways in which ITT's Astrofood endures, that in many ways the westernized diet is Astrofood-like, potentially contributing to life in distress for both commensal microbes and the psyche of the human host.

Finally, we will open up discourse on societal priorities. The idea for Astrofood began in the midst of the Apollo lunar missions and the Vietnam War. Today, the sophisticated science of food engineering (not only taste, but positioning on shelf and advertisements for sales) as a contributor to NCDs is set within growing health inequalities and massive gaps in socioeconomic status (SES). Such engineering, now a large-scale Astrofood-effort, is currently set within enduring wars and a zest for human Mars exploration. We will return to some of the less-publicized ideas presented at the 1969 White House Conference on Food, Nutrition and Health.

We underscore at the outset that food technology and the processing of food provides untold value to human health and well-being. So, too, has individual nutrient fortification proven its value in public health. Our commentary isn't a "back to nature" effort. However, in the context of environmental justice, we ask, what are the societal costs of ignoring or providing only minimal investments toward 
exploring the science of nutrition for mental health, and to what extent inequalities-nutritional and otherwise-are actually engineered? To what extent (to borrow terms from Rene Dubos [11]) does intellectual dishonesty and escapism burden the channels of food technology as it pertains to the defense of ultra-processed foods? Answers to such questions are a critical part of the grand challenge set forth by the United Nations in its recently declared Decade of Action on Nutrition (2016-2025) [12].

\subsection{Helping Out-Development of $H-11$}

Astrofood was developed under its laboratory name of $\mathrm{H}-11$. The backbone of $\mathrm{H}-11$ was ITT's Twinkies which the company described as a "fun-food". ITT had purchased the Continental Baking Company in 1968; although Twinkies enjoyed popularity when ITT assumed control, they used powerful marketing and manufacturing strategies to elevate the sales of Twinkies to lofty heights and facilitate their place in American cultural folklore. By the mid-1970s, American consumers purchased 700 million of the snack cakes [13]. Although sugar remained the dominant ingredient, the composition of Twinkies differed from its simple, short-shelf-life origins when they debuted in 1930; the ingredient list and shelf-life grew steadily under the watch of ITT (1968-1984).

The challenge for ITT's modified-Twinkie breakfast was twofold-get some protein and vitamins into H-11, and do it cheaply. The pledge to defeating hunger at breakfast was heavy on rhetoric and light on funding. But ITT was committed to delivering a breakfast on a $15 \notin$ federal budget, of which $7 \notin$ had to be devoted to the carton of milk. Cotton described the Astrofood formulation process and final product in the journal Cereal Science [14] and the Journal of the American Oil Chemists Society [15]. Emulsification, the addition of vegetable oil rich in the omega- 6 fatty acid linoleic acid and synthetic vitamins (heat-sensitive vitamin C and B1 added into the vegetable oil solids-based "cream" after the baking process) facilitated formulation. Inexpensive soy protein helped provide the minimum of $5 \mathrm{~g}$ of protein. Since the USDA set no restrictions on total carbohydrate or sugar content of the breakfast supplement (but they did set a maximum fiber content of $0.8 \%$ ), the product, much like the Twinkies backbone, was dominated by sugar.

ITT knew there were concerns that a high-sugar cake-like product could promote dental caries but these were speculatively tempered by Cotton: "We have reason to suspect that highly emulsified, fat-containing cake with creamed filling will clear the mouth faster, leaving less compacted food matter than, say, a dry cracker. Because the cake is taken with milk, we believe the mouth should clear quickly". The company proceeded to test $\mathrm{H}-11$ as a pilot project in several schools within the Northeastern US. Cotton touted anecdotal reports that children were more likely to be present at school, and while there, more attentive and less sleepy [1]. These claims were never substantiated.

Nevertheless, during the week of 22 March 1971, the Chairman of the Board of ITT Continental Bakery, R. Newton Laughlin, and President, M. Cabell Woodward Jr., blanketed big-market newspapers with an identical advertisement, near-full-page, titled with bold block letters: "An Important Message to Every Mother in America". The message concerned ITT's commitment to nutritional wellbeing:

"Our Hostess Cakes provide sound nutrients as well as good taste. As a mother, you know how important this is. As a further step in our efforts to contribute as much as we can to America's nutritional wellbeing, we developed "Astrofood". This specialized breakfast food is designed to help provide children with the nutrients they need for greater attentiveness and learning capacity. Especially important to children in underprivileged areas, Astrofood is being made available to schools across the nation. ITT Continental baking worked with the US Department of Agriculture on this project" [16,17].

H-11, an ultra-processed mix of sugar, omega-6-rich vegetable oil, soy flour, soy protein isolate and emulsifiers officially became Astrofood, a government-approved breakfast. The name appealed to children; ITT had worked with NASA on many ventures in the Apollo program. It was a watershed moment, the era of highly-processed foods had begun in earnest, and mothers were being reassured that multinational corporations such as ITT were collaborating with trusted public agencies to promote health, especially in society's most vulnerable, through optimal nutrition. Although Astrofood was by no means the first ultra-processed food developed [6,18], it maintains a notable place in history as 
exemplifying superficial attempts to address complex societal problems with the motivation of the lowest common denominator-profit.

\subsection{Processing the Legacy of Astrofood}

Through pressure from nutrition groups concerned about sugar intake, and public advocates of whole food nutrition, the fortified-baked goods supplemental breakfast program was due to expire on 30 June 1978. However, after immense industry pressure, the Chair of the House Agriculture Subcommittee, Representative Jamie Whitten, held an unusual closed-door meeting on Astrofood; the result of the meeting was maintenance of the rules that allowed for Astrofood. When asked, Whitten could provide no explanation for why the Committee meeting was held outside the public eye, other than to say "so we could thrash these things out". His explanation for maintaining the breakfast cake loophole was that "no one in Washington should say what is best for everyone in the country" [19].

Over time Astrofood as a specific product would be phased out; however, the legacy of engineered, ultra-processed foods remains, and the contribution of such foods to chronic NCDs and other pressing issues of our time looms large. In order to emphasize the historical importance of Astrofood in the annals of nutrition transition history, it may be helpful to distinguish between food processing and ultra-processed foods.

The modification of nourishing substances has been part of the human experience since time immemorial. Scientific endeavors at ancient sites reveal the extent to which humans have used fire, grinding stones, fermentation and other modification techniques to extract and preserve nutrients over the millennia $[20,21]$. Modern freezing, canning and various forms of packaging have provided immeasurable value to public health as they facilitate the widespread distribution of safe, healthy and nutritious foods. Today, multinational corporations within the food industry (and industry-supported scientists) remind both academic and lay readers that most foods are "processed" in the aforementioned ways. However, conflating ancestral fermentation, canned salmon and frozen spinach with Twinkies and carrageenan-rich, textured meat patties in the context of being processed (that is, avoiding criticism of contemporary industrial food processing) is, in our opinion, an act of intellectual escapism, if not intellectual dishonesty.

To cut through this noise and define food processing in the forms where it might present a threat to human and ecological health, the World Health Organization and leading public health scientists now refer to "ultra-processed" foods. These are not the modified foods used by our ancestors or the cheeses and pressed olive oil of the Mediterranean diet; rather they are "formulations" made mostly or entirely from substances (originally derived from whole or minimally-modified foods) and additives, reassembled but with little, if any, intact whole food within the formulation [22]. These foods mostly include ingredients not usually used in a domestic kitchen - hydrogenated fats, modified starches, protein isolates, emulsifiers, artificial sweeteners and flavorings et al. [23]. Whereas traditional cheeses might have 3 or 4 ingredients, the ultra-processed variety destined for 'macaroni and cheese' might have 2 dozen. Despite what industry front groups might suggest, most consumers are well aware of the differences between ultra-processed foods and traditional food processing [24].

Public health experts underscore the ability of ultra-processed foods to dominate and displace healthier, minimally-modified foods: "The nature of the ingredients, the various processing techniques and the sequences of stages used by the industry to manufacture ultra-processed foods are designed to create durable, accessible, convenient, hyper-palatable, highly profitable ready-to-eat, ready-to-drink or ready-to-heat products liable to displace all other...food groups" [22]. Available evidence shows that ultra-processed foods do indeed displace their healthier whole-food and minimally-modified counterparts, with greater consumption of ultra-processed foods linked with high consumption of free sugars and total, saturated and trans fats, and with low consumption of protein, dietary fiber, and various vitamins and minerals [25-27]. Moreover, research indicates that ultra-processed foods contribute to the physiological changes (e.g., elevated blood glucose, blood lipid alterations, adiposity) which link these foods to risk of NCDs and mortality [28-33]. Even in children, early-life exposure to ultra-processed 
foods is associated with blood lipid alterations which may place the individual on a trajectory to subsequent risk of NCDs [34].

Today, consumer packaged (ready-to-heat, ready-to-eat) foods with a high degree of industrial processing [35], and ultra-processed foods in particular, have become a major part of the diet in westernized nations, aboriginal peoples within such countries, and increasingly so in developing nations. For example, in North America, ultra-processed foods represent $50 \%$ or more of energy intake $[27,36]$, while in transitioning nations, such as Brazil and Chile, they represent approximately $30 \%$ of energy intake [37,38]. Across Europe, household availability of ultra-processed foods varies widely, on average they represent $26 \%$, but in the United Kingdom the household purchases are over 50\% [30]. Among First Nations people in Canadian Provinces, ultra-processed foods now provide 54\% of daily energy intake [39]. Food technology has brought inexpensive "instant" noodles to the table, and only recently are scientists catching up with the health-related consequences of their encroachment into traditional dietary patterns in Asia and beyond [40-42].

The Framingham Heart study began in the U.S. about the same time H-11 was transitioning to Astrofood. Recently researchers examined whether or not the residential food environment among the subjects of the study (in four distinct geographic areas of the Northeast, U.S.) had changed. Today the average number of fast-food outlets in proximity to the home and work of each subject has increased 5-fold [43]. In a nationwide study of U.S. veterans, it was reported that they have an average of 8 fast-food outlets within a one-mile radius of home [44]. Fast-food expansion in China-hundreds of McDonald's and Kentucky Fried Chicken outlets are opening annually, far faster than their expansion in the continental U.S.-is a surrogate marker for alterations to the global nutritional environment [45]. Highly-recognizable, branded fast-food outlets are not alone; they are part of food swamps that include take-away shops, unbranded or local fast-food outlets, convenience stores, and the expansion of gasoline/petrol stations as purveyors of sugar-added drinks, snacks and main ready-to-eat meals [46-48]. Ultra-processed foods often find a dominant place in vending machines within academic settings [49-51].

The harsh reality is that ultra-processed foods are on the global menu. Astrofood was designed, at least superficially, as a cheap way to help undo nutritional problems associated with poverty and disadvantage in children. Hunger and malnutrition remains a global problem; however, inexpensive, nutrient-poor, calorie-dense, ultra-processed foods and drinks are now consumed in the greatest amounts by the most vulnerable in society. This is not exclusively a problem in wealthy, developed, westernized nations. In one of the largest studies of its kind, collaborators of the International Study of Childhood Obesity, Lifestyle and the Environment (ISCOLE) reported that around the world, at various levels of national development, unhealthy dietary patterns are strongly related to SES-children in lower income groups consistently have unhealthy dietary patterns [52].

\subsection{Nutrition for Mental, Cognitive Health}

At the 1969 White House Conference on Food, Nutrition and Health, there was broad agreement that the provision of quality nutrition (and undoing hunger) was an essential prerequisite to cognitive development, attention, and academic performance. However, outside of gross nutrient deficiencies, there was little in the way of research at that time to substantiate the effects of specific dietary patterns and nutrient combinations in relation to brain, behavior and emotional health. The idea that dietary quality and modest nutrient inadequacies might play an important role in mental health was an outlier in medical discourse [53].

Nearly half-a-century on, international research indicates that breakfast quality (both in school programs and in general) can support normal mood, behavior and cognitive performance in children [54-57]. Indeed, a breakfast with lower glycemic load (that is, one opposite to Astrofood) has been specifically shown to support mood and cognition in children in the two to three hours following a meal [58-60]. Moreover, in a 2017 breakfast study, researchers reported that a high-fat/high sugar "toasted sandwich" and chocolate milk-type beverage caused reductions in hippocampal-dependent 
learning and memory in healthy young adults after only four days [61]. Skipping breakfast has also been linked to depression, anxiety and high levels of stress throughout the life course, and this is pronounced in association with socioeconomic disadvantage [62-64].

However, our discourse isn't about breakfast per se; rather, we underscore the increasingly robust research in the realm of "nutritional psychiatry" to highlight that the widespread encroachment of ultra-processed foods, fast-food, and energy-dense-nutrient-poor foods is a barrier to the fulfillment of human potential. Traditional, dietary patterns (exemplified by the Mediterranean diet) have been associated with good emotional and cognitive health, as well as lowered risk of depression and attention deficit hyperactivity disorder [65-67]. On the other hand, greater adherence to the westernized diet is associated with a smaller hippocampus, the area of the brain crucial to aspects of memory [68]. Short-term intervention studies based on such traditional or low-glycemic dietary patterns have shown benefit for individuals with depression, as well promoting positive mental outlook, benefits in memory and alleviation of fatigue [69-73].

\subsection{Deconstructing Astrofood}

From a biological perspective, Astrofood was built on the assumption that the delivery format of macro/micro nutrients was largely irrelevant and "new food" combinations (pieces of nature mixed in with additives) could easily replace the old foods; that is, the old delivery "format" in the form of whole foods-to which the genus Homo was accustomed for nearly 3 million years-was outdated. However, ancestral nutritional experience didn't prepare consumers of Astrofood (and the ultra-processed foods it represents) for the ways in which its parts were assembled into the whole cake.

First, the ratio of omega- 6 to omega- 3 fatty acid in ancestral nutritional experience was very close to 1:1. With the mass introduction of linoleic-acid-rich vegetable oils, such as that in Astrofood, the omega- 6 to omega-3 ratio in the westernized diet is now around 16:1, and in some transitioning nations is as high as 50:1 [74]. Dominance of omega-6 relative to omega-3 has been linked to obesity, depression and childhood learning and behavioral disorders [75-78]; Second, added sugars, also foreign to ancestral experiences, have been linked with depression and behavioral disorders in human and animal research; mechanisms by which sugar could provoke mood, cognitive or behavioral disturbances include diminished levels of brain derived neurotrophic factor (BDNF) that otherwise supports stability and growth of nerves even past middle-age, elevation of inflammatory immune proteins such as cytokines (the elevation of which can compromise mood, disturb cognitive focus and increase anxiety), changes in blood-glucose-insulin control (which can effect subsequent mood), and addiction-like effects of sugar and sugar-fat combinations working through dopamine-mediated reward centers in the brain [79-81]. The effects of highly-palatable sugar or sugar-fat combinations may be especially disruptive to brain and behavior when encountered early in life [82].

Although soybeans have been a staple in Asia, the historical dietary intake was through fermented pastes, tofu and milks. Soybeans contain isoflavones which are natural chemicals with estrogen-like properties. In the Astrofood era, North American food engineers found "new food" applications for highly-processed isolated soy proteins and textured vegetable proteins, including soy $[83,84]$. These new food forms of soy are particularly rich in phytoestrogens. For example, textured soy protein contains over 8 times more phytoestrogens than soy milk [85]. Since new food soy was allowed to be mixed into a wide variety of meat products at levels up to $30 \%$ (meat labeled as patties, sausage, meatballs et al) including school lunches and multitudes of processed foods [86], it is nearly impossible to get a realistic idea of soy intake in North America (for example, a "meat" consumer who refrains from tofu and soymilk may not realize they are a soy consumer when asked on dietary recall studies). From our perspective of mental health, it is worth noting that several animal studies have shown soy isoflavones to increase anxiety-like behavior in males [87,88]. In humans, a J-shape curve has been reported wherein higher levels of soy intake have been associated with depression [89].

Since Astrofood was a combination of sugar and protein baked at high temperatures, we speculate that it would have been high in advanced glycation end-products (AGEs). These are highly oxidant 
compounds formed through the non-enzymatic reaction between reducing sugars and free amino acids. AGEs are particularly abundant in westernized foods prepared with high heat in the absence of water (i.e., oven-baked goods). For example, a biscotti, with its oven-baked combination of protein and sugar, is extraordinarily high in AGEs-over 35 times higher than a poached egg [90]. This is of relevance because foods high in pre-formed AGEs have been linked to inflammation, oxidative stress and enhanced allergenicity of foods [91-93]; on the other hand, dietary interventions to lower exogenous AGE intake can significantly reduce systemic inflammation and oxidative stress [94].

The unspecified emulsifiers and synthetic additives will be addressed further in the dysbiosis section below. It is unclear if Astrofood was inclusive of artificial food colorants; Twinkies did include synthetic colors and flavors in the 1970s. Levels of artificial food dyes available in many markets have witnessed exponential growth-since 1968 the upper range of synthetic food dye in cereals has risen by almost 3-fold, and the amount in baked goods by over 3.5-fold-with early life intake far higher than previously estimated [95]. Synthetic food additives, especially colorants and preservatives, are under increased scrutiny; biologically they have been linked with inflammation [96], and behavioral problems which may not be exclusive to ADHD [97-99]. Many questions surround carrageenan, a seaweed derivative added to numerous foods for texture, binding and thickening (for example, carrageenan can be added to meat products in levels over one gram per patty [100]); it has been linked with inflammation in numerous experimental studies [101].

\subsection{Dysbiosis-Life in Distress}

The term microbiome refers to microbes and their collective functional genomes operating within an ecological niche [102]. When Astrofood was formulated there was only limited appreciation for the important role played by gut microbes in human health, and their interaction with diet and stress $[103,104]$. Today we know that the microbiome plays a functional role in nutrient absorption, manufacture of beneficial bioactive chemicals (e.g., short chain fatty acids and transformed phytochemcials), protection against pathogens, maintaining gut/skin and other barriers to the outside environment, reducing the burden of potentially-harmful environmental chemicals (xenobiotics). Microbes also "educate" the immune system in early life such that it can make appropriate, adaptive responses to the environment. Put simply, humans have evolved with microbes with mutual benefit.

Functional roles played by the microbiome are often discovered by observations following dysbiosis. Translating from its Greek root as "life in distress", it is defined in the context of microbiology as disruptions to the structure of complex commensal microbial communities, involving one or more of the following: loss of beneficial microorganisms, and/or the expansion of potentially harmful microbes, and/or the loss of overall microbial diversity [105]. Dysbiosis can be induced by stress, antibiotic administration, and is of high relevance to Astrofood, high-sugar/high-fat ultra-processed foods. Clues suggesting that dysbiotic microbes play a functional role in depression, anxiety, obesity and other NCDs can be found in fecal transfer studies. That is, when fecal material from either healthy adults or those with NCDs (e.g., obesity or depression) is transplanted into healthy rodents, there are clearly observable metabolic and behavioral disturbances in animals that were the recipients of dysbiotic donor stool [106-108].

While an "ideal" healthy gut microbiome remains elusive, it is generally accepted that gut microbiome diversity equates to healthy lifestyle habits, especially diet. This is illuminated through the examination of relatively isolated groups of people who still maintain their way of life in pre-Astrofood ways. Living in ways that closely resemble our hunter-gatherer and early subsistence ancestors-diets rich in minimally-processed foods, plants, fiber and devoid of ultra-processed fare-these groups seem particularly resistant to NCDs. With a good degree of consistency, researchers have shown general losses in microbial diversity in association with westernization and industrialization $[109,110]$. The loss of microbial diversity as a result of what Astrofood represents-that is, an ultra-processed, reassembled food supply deficient in fiber and phytochemicals-may have long-term consequences $[111,112]$ and 
even extend over generations [113]. As in the larger world of natural environments, loss of microbial diversity generally equates to a loss of functional benefits and threat to a healthy ecosystem.

Recalling the Astrofood deconstructed section above, we can now point out that beyond the high sugar content [114], the various components of this ultra-processed breakfast have now been associated with dysbiosis of gut microbiota. For example, animal studies have linked AGEs [115], emulsifiers [116-118], excess omega-6 oil [119] and soy protein [120] with dysbiosis and inflammation. In recent animal research, carrageenan has been shown to reduce levels of an intestinal microbe which otherwise protects the intestinal lining and prevents inflammation [121]. Thus, ultra-processed foods are, as an ingredient collective, a potential threat to normal cognition, mood and behavior by virtue of their macronutrient profile, additives, and their missing parts.

In agreement with the minimally-processed, whole foods (Mediterranean style) diet interventions shown to improve mood and cognition (as mentioned above), emerging research is demonstrating, at least over the short-term, that such foods provide neuro-emotional benefit via the microbiome [122,123]. While still in its infancy, a small but growing list of controlled human studies indicates that oral microbial products (probiotics or nutritional substrates that confer benefit via microbial activity) can improve aspects of mood, cognition, stress and/or anxiety [124-127]. The mechanisms by which microbes can influence brain development, cognition and behavior include, but are not limited to: direct and indirect microbial interactions with the immune system, enhancement of nutrient bioavailability and neurotransmitter precursors, maintenance of the gastrointestinal lining, reduction of oxidative stress, direct gut microbe-to-brain communication via the vagus nerve which connects the intestinal tract to the emotional centers of the brain, and transformation of dietary phytochemicals into bioactive compounds which subsequently influence mood [21,128]. But as we will explore in more detail below concerning the cost of diets, the application of probiotics and specialized fermented products are expensive and unlikely to represent a primary solution to the nutritional drivers of NCDs [129]. In other words, Astrofood wouldn't have been complete if it had a probiotic in its cream-like filling.

\subsection{Extinction of Experience, Nature Relatedness}

Changes in lifestyle in concert with screen-based technology has accelerated childhood disconnection from the natural environment, a phenomenon researchers have termed "extinction of experience" [130]. Childhood connections to nature can influence environmental attitudes and promote the psychological asset known as nature relatedness [131]; nature connection, as measured by Nature Relatedness or Nature Connectedness scales has been linked to mental well-being in a variety of studies [132,133]. We consider Astrofood-as a surrogate marker for a sugary, synthetic attempt to fill in the extinction of ancestral experience with minimally-processed, nutrient dense foods- to be part of the total disengagement, a fragmentation of nature wrapped in cellophane.

To appreciate how daily Astrofood would potentially cue a disconnect from nature, we can look to research in the realm of gardening in academic and community settings. Participation in gardening programs brings children in touch with food and nature at the same time [134]. Indeed, gardening increases nature-connectedness as an asset of health and well-being [135]. Among the many benefits noted by researchers, gardening promotes positive mental outlook and healthier behavior in general, including increased physical activity. Of special note here in our context, gardening has been linked with subsequent increases in fruit and vegetable intake, and reduced fast-food consumption [136-138]. Relationships between child and food along a continuum of whole foods to Astrofood in the context of nature relatedness warrants exploration.

\subsection{Engineering Policy, Marketing Dysbiosis}

The larger plan of ITT was to bring the Astrofood breakfast to supermarkets and shops, hence its nationwide ad campaign targeting "every mother in America". Indeed, the ties between ITT and the USDA were so strong that the latter mandated that the former must bring the breakfast cakes to market. 
In a 1972 nationally-syndicated opinion piece, noted science and policy journalist Daniel Zwerdling provided a nutritional forewarning:

"Under agriculture regulations, any food developed for the breakfast programs must eventually be sold commercially in neighborhood markets. ITT Continental is already test marketing Astrofood in a few cities. In a few years, all the protein and vitamin-packed puddings and candies and soft-drinks developed at government expense for the breakfast program will spill out onto the market shelves" [139].

Today, there is little doubt that marketing calorie and sugar-dense breakfast products (most notably, cereals) towards parents and their children is a multi-billion-dollar investment on the part of global corporations [140-142]. Marketing investments in sugary breakfasts pay off handsomely for manufacturers, with research showing clear lines between ad exposure and greater childhood consumption [143]. Similar relationships between ad exposure and greater childhood fast-food consumption have also been reported [144]. Indeed, there is enough research in place to move beyond mere associations, these ad-to-consumption patterns are now in the realm of causation [145]. Children from low-income urban areas in the U.S.- despite free access to better quality school breakfast programs-often skip the breakfast altogether, or opt instead for nutritionally-poor dietary breakfast choices made at local convenience shops [146].

As highlighted by scholar Selena Ortiz and colleagues in Social Science and Medicine (2016), food engineering in the contemporary environment goes beyond manipulations of sugar, fat, sodium and chemicals to enhance taste, texture, and palatability. This physiological form of engineering is accompanied by cognitive engineering in the form of effective marketing mentioned above-advertisements, celebrity endorsements, toy giveaways, "health-halo" label claims, and vague terminology such as "nutritious" which collectively appeal to the mind of the parent and/or child consumer. The third form of engineering is the manipulation of the total food environment via product placement and prominent shelf-space devoted to ultra-processed, energy-dense, low-nutrient foods [147].

We will address the burden of total food engineering on socioeconomically disadvantaged communities shortly, but for now we point out that these forms of food engineering proliferate because policy (or in many cases, lack of policy through lobbying efforts) is itself engineered. In other words, the westernized nutritional environment viewed in its totality is a product of neoliberal policies which allow the drivers of NCDs (including ultra-processed foods) to sit on-shelf with commercially available remedies (e.g., pharmaceuticals, supplements). Under neoliberalism, personal responsibility for a healthy lifestyle is heralded to be the sole road to fulfilling potential in life [148-150].

At the same time, the largest names in the food industry have increasingly partnered up with government-just as they did in the early days of Astrofood-in highly visible forms of so-called public-private partnerships. The optics of these efforts look good to the public; fast-food, soft drink and ultra-processed food companies appear to care deeply about obesity and NCDs. In reality many are simply an extension of cognitive engineering [151,152], a place where a "cholesterol-free" label on a soft drink bottle is transported to a grand scale. Sponsorship of major health organizations and dietetic conferences is part of the systemic approach; however, when faced with new legislation that might curb sales, purveyors of soft drinks are swift in opposition- $97 \%$ of the time, according to recent U.S. research. Indeed, the financial investments in lobbying efforts are at an astronomical scale-more than $\$ 10$ million USD per year on the part of Coca-Cola, PepsiCo and the American Beverage Association [153].

\subsection{Disadvantage Compounded}

One of the formidable challenges for academics working within health arenas-nutritional and otherwise-is to understand the interconnected ways in which the total lived experience of individuals meets with single "exposures" [154]. The implications of emerging nutritional psychiatry and nutritional dysbiosis research, while relevant for all, are most pronounced for vulnerable populations. The risk of mental disorders in populations, most notably depression, does not occur randomly in 
developed nations. Rather, the gradient of risk is steeply slanted toward the disadvantaged [155-159]. From the nutritional perspective, childhood adversities (which already increase risk of later-life NCDs) predict subsequent unhealthy dietary choices in adulthood [160].

Put simply, as much as modern research allows us to deconstruct the individual ingredients of Astrofood and determine their possible effects on dysbiosis, the product is consumed as a whole and it meets with the unique biophysiology of the individual. The latter is determined by collected experiences in the total environment over time, which forces discussions of disadvantage. For young consumers of Astrofood (the ultra-processed food it represents today) and their parents, the total food engineering package described above is likely to be more prominent in day-to-day life.

As we have described in detail elsewhere, research shows that the many forms of socioeconomic disadvantage can translate into a disparate physical and mental environment. The living environment is likely to have a disproportionate number of convenience stores and fast-food outlets. The visible marketing materials on billboards and sidewalk signage are more likely to be dense and cajole unhealthy lifestyle choices. The availability of inexpensive, energy-dense, low nutrient foods is common; in-store, the shelf-space, point-of-purchase options and promotions magnify the position of ultra-processed foods [161,162]. At the same time, the disadvantaged environment is less likely to have adequate access to healthy foods; since indoor screen time is connected to snacking and dietary habits, the decreased likelihood of safe, well-managed natural environments for play is also a factor which dictates the interface of ultra-processed foods and biological responses to food.

Disadvantaged families experience higher chronic psychosocial stress and daily hassles; individual and neighborhood-level deprivation have been associated with significantly higher biomarkers of metabolic dysregulation, inflammation and oxidative stress [163-171]. Even if the sugary Astrofood breakfast were given to all students—affluent and low-income-the postprandial responses over time would likely differ. Evidence shows that the healthier background diets of affluent families would help buffer the effects of Astrofood; for example, several studies have shown that tissue levels of phytochemicals and antioxidants-the sort that would buffer the effects of inflammation and metabolic dysregulation-are higher in association with individual and neighborhood SES advantage [172-178]. Research has shown that neighborhood disadvantage is associated with lower diversity of the intestinal microbiome; the gut microbial ecology coincident with deprivation (mostly through ultra-processed dietary patterns) may play important roles in metabolic disturbances [179].

\subsection{Remediation, Broken System}

Critics of Astrofood were primarily concerned with its sugar content and the message that it sent to children regarding nutrition. If a cake-like substance was good enough for breakfast at school, these early-life experiences might shape relationships with food and nutrition outside of school and over the life course. We agree, and research does show that childhood dietary habits can persist into adulthood [180]. However, in our opinion, it sent (and still sends) an industry-government signal far more devastating than sugar. Astrofood represented the extreme arrogance of food technology, a place where the link between child and nature was interrupted, where disadvantage and social injustice could be remediated with cake (See Figure 1).

The broad lens view of Astrofood forces difficult questions on society; many of these questions pertain to the acceptability and maintenance of socioeconomic and health inequalities. To understand the systems which allow for the current pervasiveness of ultra-processed foods, a brief revisit to Astrofood's point of origin — the 1969 White House Conference on Food, Nutrition and Health—may be helpful. Professor Gordon E. Bivens of the University of Missouri attended as part of the Consumer Task Force and discussed his conference experiences in The Journal of Consumer Affairs (1970). Bivens noted "a heavy overlay of business representation...in some instances, the vested interests of industry seemed to affect the way in which the business of the panels-including hearings during the Conference-was conducted" [181]. He also underscored the Social Action Statement which was collectively agreed upon by various 
advocacy groups, including those representing women, students, minorities, unions and community organizations. Below are some of the primary points within the Social Action Statement [182].

1. Shift nutrition programs out of the USDA and to the U.S. Department of Health, Education and Welfare; "there is a conflict of interest established in the USDA in its dual role-primarily the advocate for the producers of food, and secondarily the distributor of food to the needy".

2. Free school breakfast and lunch should be offered regardless of parental income, and "nutritious food (should be) selected...while respecting cultural food preferences".

3. The overriding remedy for hunger and malnutrition is adequate income and a "living wage"; extending the right to all working people to collectively bargain for those wages, as well as working hours and conditions.

4. Mandatory limitation on industry marketing and promotions which inflate consumer costs; mandatory examination and standardization of food processing to "identify and preserve nutrient content".

5. Given the societal benefits, the cost of providing an equitable nutritional landscape throughout the socioeconomic spectrum is minimal; of changes to policy and practice, "none will require appropriations higher than a fraction of the cost of the space program".

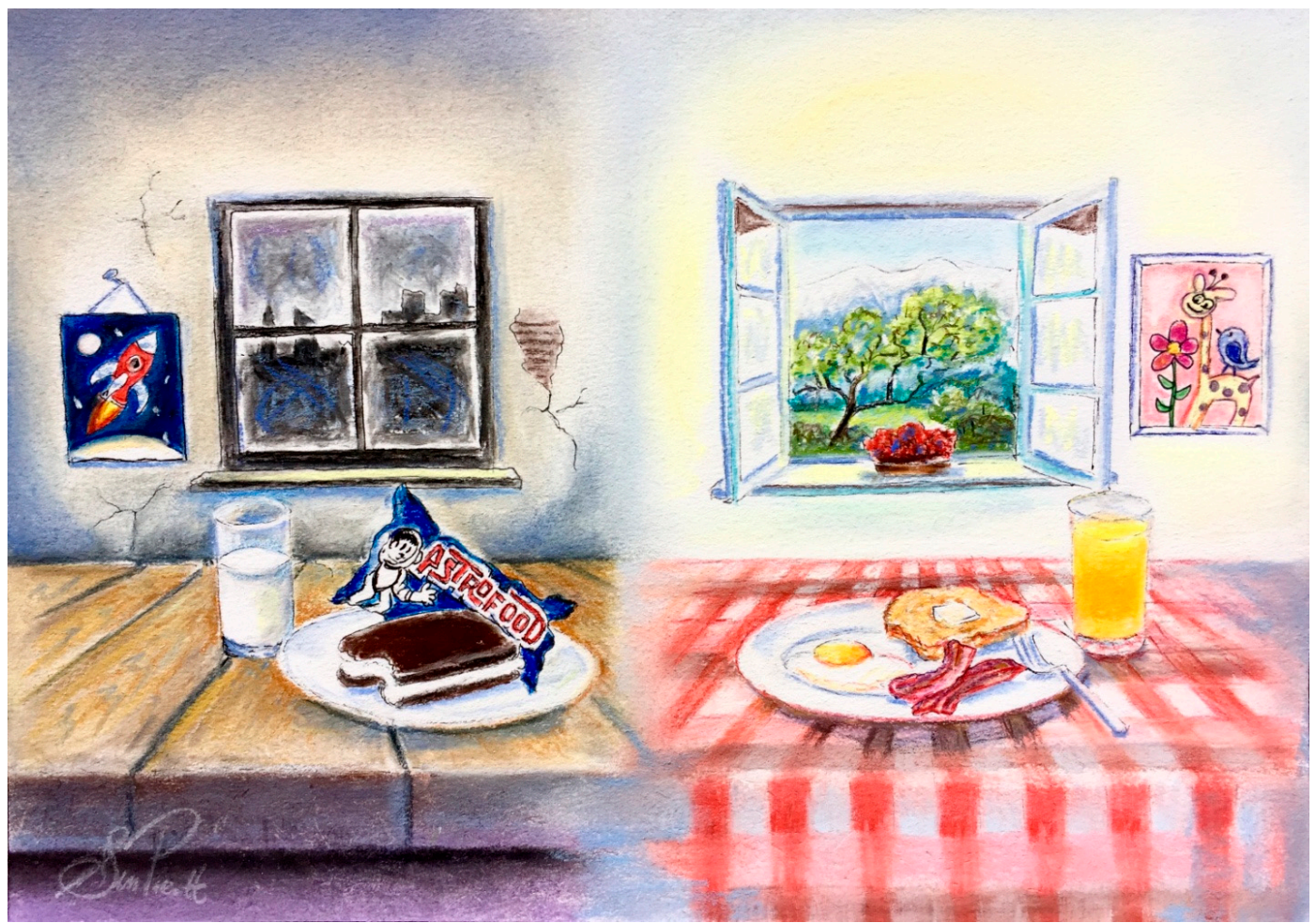

Figure 1. Remediation: In response to gross socioeconomic inequalities, disadvantage and social injustice in the total childhood environment, an ultra-processed breakfast food cake (Astrofood) was engineered and marketed for its "nutritional" equivalency. Its legacy remains in plain sight (Image: Susan L. Prescott).

Almost 50 years on, we can look back and put these perspectives into a contemporary context: By highlighting the conflict of interest, leaders who shaped the Social Action Statement were foretelling the words of the USDA Deputy Director Ed Koenig as he "got a brainstorm" with ITT's Robert Cotton as they spontaneously developed the breakfast Twinkie. From the perspective of health promotion, public health scientists and physicians in the department of health may have been better suited to evaluate what constitutes a nutritious, culturally sensitive breakfast. Although the US Health and Human Services branch now works with the USDA to craft current nutrition guidelines, many experts 
see the same industry influence; commenting on the revised 2015 nutrition guidelines, noted pediatric endocrinologist Robert Lustig (who has studied the direct effects of sugar on metabolic syndrome [183]) stated that USDA involvement is akin to "putting the fox in charge of the henhouse" [184].

The Social Action Statement of the Consumer Task Force emphasized school meals regardless of family income because they emphasized the effects of food delivery systems on dignity, highlighting stigma and the emotions felt by children who were receiving "free" food [181]. Today, we know much more concerning the mere perceptions of social exclusion and poverty when they are evoked in laboratory experiments, including how it might influence dietary choices. For example, when researchers invoke feelings of poverty, powerlessness or the perception of belonging to an under-privileged "out-group", it results in altered dietary choices in the direction of low-nutrient, high-calorie foods [185-187]. Of course, that is briefly-invoked perception in a lab, an "in situ" from which the subject can readily escape; the reality of discrimination can manifest as inflammation and metabolic dysfunction [188-190], and, as mentioned above, compound the inequity of the total environment, nutritional and otherwise.

Today, there is little doubt that a living wage is central to health equity; for example, emerging research shows that in socioeconomic position (SEP) disadvantaged workers, relatively small wage increases are associated with subsequent reductions in depression [191,192]. Lack of a living wage or stagnant minimum wages in concert with lack of welfare buffers can magnify stress and compound an unhealthy lifestyle (e.g., dietary choices) [193-196]. Alarmingly, global socioeconomic disparities continue to climb, and in the U.S. the life expectancy of the wealthiest can exceed low-income individuals by 10-15 years [197]. Over the last decade, the research supporting the nature-based Mediterranean and ancestral diets has grown increasingly robust, even extending into reducing the risk of mortality [198], but only recently has the affordability of such diets been questioned. Evidence shows they can be relatively expensive $[199,200]$. Plus, the Mediterranean diet is a broad term, and new research shows that affluent SEP predicts a variant of the diet which is richer in fruit and vegetable diversity, polyphenol and essential fatty acid intake, whole wheat consumption, less pesticide residue and low-AGE preparation of vegetables [201].

Public health has been the vanguard of defending and advancing labor standards as part of its evidence-based effort to reduce health inequalities [202]. As pointed out by professor Frank Houghton, "Public Health functions, in part at least, to help counter-balance the dominance of bio-medical approaches in the health arena" [203]. In our opinion that function extends to counter the dominance of engineering of the total food environment. In the increasingly ultra-processed, contemporary world of Twinkies, collective bargaining is a thing of the past; the company's union labor force now eliminated under new ownership, Twinkies are currently manufactured with new automation-and what was once about 4 ingredients has grown to almost 40 as the products now enjoy a 65-day shelf life [204].

In an interesting metaphorical twist to the origins of the ultra-processed Astrofood vis-a-vis its Twinkie backbone-the co-owner of Twinkies recently purchased the Playboy Mansion in Los Angeles [205]. The fantastical mansion is far afield from South Los Angeles where income is low, but ultra-processed and fast-foods are widely available [206,207]. Indeed, the nutritional landscape of South Los Angeles is a 32-square mile area which houses about $45 \%$ of fast-food outlets found within the entire 500 square mile City of Los Angeles [208]. However, some young people are beginning to view the engineered ultra-processed and fast-food environment for what it is-a matter of power, inequality and food justice. With education, youth can see the connections between a package of modern Astrofood-cake in an urban corner store, and how a purchase not only enhances dysbiosis, but funds the deed to the mansion on the other side of the city. Researchers are demonstrating that when young people see such connections, they are far more likely to understand the importance of healthy dietary patterns vs. another informational session on a dietetics pyramid or academic guideline [209-211].

The Consumer Task Force recognized the value of food processing and packaging, but their emphasis on preserving the nutrient content of foods during production and transport underscored that 
nutrient preservation should be the guiding principle. It is clear from their statement that the notion of Astrofood would have been objectionable. Moreover, the request in the Social Action Statement for government to develop innovative ways to address marketing and promotion is important. Beyond the ways in which food cues, celebrity endorsements and "free" toys influence childhood dietary choices (toward ultra-processed and fast-foods), the targeted marketing of disadvantaged communities adds to the cost of the food dollar, contributes to the dominance of unhealthy foods, and diminishes the opportunity to fulfill human potential [161,162,212]. Full page ads in leading magazines and nationwide newspaper campaigns for ITT Astrofood weren't free; they cost consumers somewhere along the line before the product was, as Koenig said, dumped by the hundreds in school hallways, before the costs at the intersection of sugar and disadvantage could be measured.

Finally, in making reference to the costs of the space program (the White House conference was mere months removed from the 20 July 1969 lunar landing), the Social Action Statement was underscoring societal priorities and commitment to equity. As we have discussed in detail elsewhere [213], the benefits to society—financial and otherwise-of an intense, collaborative "moon shot"-like effort to promote mental health and eliminate health inequalities are virtually immeasurable. Half-a-century later we are, in a sense, back to the future. In the U.S., billions in public funds are being invested in crewed missions to Mars while socioeconomic and health inequalities continue to grow, and the NCDs crisis is described as epidemic. Intellectual escapism allowed for the Social Action Statement to be ignored; just as surely as the research subject could abandon the temporary subjective feeling of poverty, so too policy makers dodged the difficult questions forced upon them. Astrofood was an easy out. But here we are, 50 years on and the very same issues raised by the Consumer Task Force are no less relevant.

The 1969 White House Conference on Food, Nutrition and Health concluded with a promissory note to hold a follow-up conference one year later. It never happened, and still hasn't. In its stead are many industry-supported conferences under the banner of dietetics, and expert papers conflating ancestral fermentation and the use of fire with polysorbate and sucralose, both positioned as forms of food processing. Moreover, the 21st century resonance of Astrofood-and its entanglement with industry-government relations-is evident at many turns. In May, 2017, the Trump administration responded to food industry lobbying and rolled back even modest attempts to restrict sodium and include minimum whole grain standards in federal school meal programs. In the announcement, the new USDA secretary claimed that removing caps on sodium and the requirement for whole grain minimums was an effort to "make school meals great again" by improving palatability [214].

\section{Conclusions}

Emerging studies in pediatric health demonstrate the overall importance of a healthy lifestyle—fruits, vegetables, whole foods, physical activity, quality sleep, avoiding ultra-processed foods and excess screen time-in academic achievement and early life mental health $[215,216]$. In scientific jargon these lifestyle variables are "exposures"; they are parts of the total lived experience with enormous implications to the individual and society as a whole, especially when viewed over time. Nutrition is one of many factors associated with childhood health adversities which predict academic achievement [217], and as such, society has an obligation to protect all of its most vulnerable.

Reexamining Astrofood through a contemporary lens allows us to place advances in nutritional psychiatry and the microbiome onto an ultra-processed product that was developed, marketed and distributed to disadvantaged children. Viewed from this biological perspective, contemporary research would suggest the product was not in favor of childhood cognitive and emotional development; rather, its ingredients are those associated with dysbiosis and inflammation according to many recent studies. However, the Astrofood rewind isn't simply an act of academic curiosity. In the contemporary environment where Astrofood-like products dominate, the same systems that allowed for its market penetration are operating today. Looking back on the origins of Astrofood and the acceleration of ultra-processed foods is an important exercise; it helps to underscore the disconnect between a 
hunger for technological applications in the interest of profits, and the mission of public health to eliminate actual hunger and literally and figuratively nourish populations such that they can meet the WHO definition of health-i.e., fulfillment of potential. In a world where some 10 billion people will need nourishing food by 2015, solutions to the grand challenges of the Decade of Nutrition will certainly require the expertise of food technology; however, the intellectual escapism and dishonesty which defends the ultra-processed foods ignores the NCDs crisis and Planetary Health. The archives of Astrofood provides clues to undoing the tangled knots which otherwise maintain an untenable status quo.

Author Contributions: Alan C. Logan and Susan L. Prescott made substantial contributions to this invited opinion article; this included acquisition, analysis and interpretation of data. Alan C. Logan and Susan L. Prescott made equal contributions to the drafting of the manuscript and intellectual content. Both agree to its total content.

Conflicts of Interest: Susan L. Prescott reports the following: Scientific Advisory Board and speakers fees from Danone Nutricia, Schiphol, Netherlands and Nestlé Nutrition Institute, Lausanne, Switzerland; consultancy fees from Bayer Inc., Whippany, NJ, USA and Swisse Wellness Australia; speakers' fees from Health World Inc., Northgate, QLD, Australia. Alan C. Logan has received consultancy fees from Genuine Health, Toronto, Canada and speakers' fees from Health World Inc., Northgate, QLD, Australia.

\section{References}

1. Cotton, R.H. Engineering in relation to nutrition: A parameter of the educational environment. In Proceedings of the 8th Annual Meeting of the National Academy of Engineering, Washington, DC, USA, 1-2 November 1971; pp. 205-217.

2. ITT. The way to a kid's head is through his stomach. The Los Angeles Times, 9 November 1971, p. 67.

3. Zwerdling, D. School kids have cake and eat it too in nutritional breakfast program. Arizona Republic, 17 September 1972, p. 27.

4. Zwerdling, D. USDA decrees: Let them eat cake for breakfast. Lansing State Journal, 12 October 1972, p. F6.

5. Zwerdling, D. If kids don't have bread for breakfast, let them eat cake. The Morning News, 25 September 1972.

6. Rosenfield, D. What's new in foods? Food Nutr. 1972, 2, 11-13.

7. ITT Advertisement. The way to a kid's head is through his stomach. Los Angeles Times, 9 November 1971, p. 67.

8. ITT Advertisement. The way to a kid's head is through his stomach. Black Enterp. 1972, 2, 53.

9. ITT. The way to a kid's head is through his stomach. Ebony 1972, 27, 134.

10. U.S. Government Printing Office. Recommended Research and Development; Superintendent of Documents; U.S. Government Printing Office: Washington, DC, USA, 1969; p. 219.

11. Dubos, R. The genius of design. In The Rest of Our Lives, Proceedings of the International Design Conference, Aspen, CO, USA, 15-20 June 1969; Chermayeff, I., Wolf, H., Eds.; IDCA Printing: Aspen, CO, USA, 1969; pp. 57-63.

12. United Nations Decade of Action on Nutrition (2016-2025): Work Program. Available online: http://www. who.int/nutrition/decade-of-action/workprogramme-doa2016to2025-en.Pdf (accessed on 20 August 2017).

13. Black, C. Twinkies have a strong following. Asbury Park Press, 6 February 1976, pp. 58, 60.

14. Cotton, R.H.; Allgauer, A.J.; Nelson, A.W.; Koedding, D.W.; Baldwin, R.R. Astrofood: A fortified baked product with creamed filling. Cereal Sci. Today 1971, 16, 188-189.

15. Cotton, R.H. Soy products in bakery goods. J. Am. Oil Chem. Soc. 1974, 51, 116A-119A. [CrossRef]

16. Laughlin, R.N.; Woodward, M.C. An important message to every mother in America. The Los Angeles Times, 22 March 1971, p. 70.

17. Laughlin, R.N.; Woodward, M.C. An important message to every mother in America. Tucson Daily Citizen, 24 March 1971, p. 18.

18. Lachance, P.A. Nutrification: A concept for assuring nutritional quality by primary intervention in feeding systems. J. Agric. Food Chem. 1972, 20, 522-525. [CrossRef] [PubMed]

19. Anderson, J. Sweet deal. The Times Herald, 24 May 1978, p. 10A.

20. Mariotti Lippi, M.; Foggi, B.; Aranguren, B.; Ronchitelli, A.; Revedin, A. Multistep food plant processing at Grotta Paglicci (Southern Italy) around 32,600 cal b.P. Proc. Natl. Acad. Sci. USA 2015, 112, 12075-12080. [CrossRef] [PubMed] 
21. Selhub, E.M.; Logan, A.C.; Bested, A.C. Fermented foods, microbiota, and mental health: Ancient practice meets nutritional psychiatry. J. Physiol. Anthropol. 2014, 33, 2. [CrossRef] [PubMed]

22. Monteiro, C.A.; Cannon, G.; Moubarac, J.C.; Levy, R.B.; Louzada, M.L.; Jaime, P.C. The UN decade of nutrition, the nova food classification and the trouble with ultra-processing. Public Health Nutr. 2017. [CrossRef] [PubMed]

23. Scrinis, G.; Monteiro, C.A. Ultra-processed foods and the limits of product reformulation. Public Health Nutr. 2017. [CrossRef] [PubMed]

24. Ares, G.; Vidal, L.; Allegue, G.; Gimenez, A.; Bandeira, E.; Moratorio, X.; Molina, V.; Curutchet, M.R. Consumers' conceptualization of ultra-processed foods. Appetite 2016, 105, 611-617. [CrossRef] [PubMed]

25. Louzada, M.; Ricardo, C.Z.; Steele, E.M.; Levy, R.B.; Cannon, G.; Monteiro, C.A. The share of ultra-processed foods determines the overall nutritional quality of diets in Brazil. Public Health Nutr. 2017. [CrossRef] [PubMed]

26. Martinez Steele, E.; Popkin, B.M.; Swinburn, B.; Monteiro, C.A. The share of ultra-processed foods and the overall nutritional quality of diets in the U.S.: Evidence from a nationally representative cross-sectional study. Popul. Health Metr. 2017, 15, 6. [CrossRef] [PubMed]

27. Moubarac, J.C.; Batal, M.; Louzada, M.L.; Martinez Steele, E.; Monteiro, C.A. Consumption of ultra-processed foods predicts diet quality in Canada. Appetite 2017, 108, 512-520. [CrossRef] [PubMed]

28. Fardet, A.; Mejean, C.; Laboure, H.; Andreeva, V.A.; Feron, G. The degree of processing of foods which are most widely consumed by the French elderly population is associated with satiety and glycemic potentials and nutrient profiles. Food Funct. 2017, 8, 651-658. [CrossRef] [PubMed]

29. Mendonca, R.D.; Lopes, A.C.; Pimenta, A.M.; Gea, A.; Martinez-Gonzalez, M.A.; Bes-Rastrollo, M. Ultra-processed food consumption and the incidence of hypertension in a mediterranean cohort: The Seguimiento Universidad de Navarra Project. Am. J. Hypertens. 2017, 30, 358-366. [CrossRef] [PubMed]

30. Monteiro, C.A.; Moubarac, J.C.; Levy, R.B.; Canella, D.S.; Louzada, M.; Cannon, G. Household availability of ultra-processed foods and obesity in nineteen European countries. Public Health Nutr. 2017, 1-9. [CrossRef] [PubMed]

31. Costa, C.S.; Del-Ponte, B.; Assuncao, M.C.F.; Santos, I.S. Consumption of ultra-processed foods and body fat during childhood and adolescence: A systematic review. Public Health Nutr. 2017, 1-12. [CrossRef] [PubMed]

32. Mendonca, R.D.; Pimenta, A.M.; Gea, A.; de la Fuente-Arrillaga, C.; Martinez-Gonzalez, M.A.; Lopes, A.C.; Bes-Rastrollo, M. Ultraprocessed food consumption and risk of overweight and obesity: The university of Navarra follow-up (sun) cohort study. Am. J. Clin. Nutr. 2016, 104, 1433-1440. [CrossRef] [PubMed]

33. Rezende, L.F.; Azeredo, C.M.; Canella, D.S.; Luiz Odo, C.; Levy, R.B.; Eluf-Neto, J. Coronary heart disease mortality, cardiovascular disease mortality and all-cause mortality attributable to dietary intake over 20 years in Brazil. Int. J. Cardiol. 2016, 217, 64-68. [CrossRef] [PubMed]

34. Rauber, F.; Campagnolo, P.D.; Hoffman, D.J.; Vitolo, M.R. Consumption of ultra-processed food products and its effects on children's lipid profiles: A longitudinal study. Nutr. Metab. Cardiovasc. Dis. 2015, 25, 116-122. [CrossRef] [PubMed]

35. Poti, J.M.; Mendez, M.A.; Ng, S.W.; Popkin, B.M. Is the degree of food processing and convenience linked with the nutritional quality of foods purchased by U.S. households? Am. J. Clin. Nutr. 2015, 101, 1251-1262. [CrossRef] [PubMed]

36. Martinez Steele, E.; Baraldi, L.G.; Louzada, M.L.; Moubarac, J.C.; Mozaffarian, D.; Monteiro, C.A. Ultra-processed foods and added sugars in the U.S. diet: Evidence from a nationally representative cross-sectional study. BMJ Open 2016, 6, e009892. [CrossRef] [PubMed]

37. Cediel, G.; Reyes, M.; da Costa Louzada, M.L.; Martinez Steele, E.; Monteiro, C.A.; Corvalan, C.; Uauy, R. Ultra-processed foods and added sugars in the chilean diet (2010). Public Health Nutr. 2017. [CrossRef] [PubMed]

38. Louzada, M.L.; Martins, A.P.; Canella, D.S.; Baraldi, L.G.; Levy, R.B.; Claro, R.; Moubarac, J.C.; Cannon, G.; Monteiro, C.A. Consumption of ultra-processed foods and obesity in Brazilian adolescents and adults. Rev. Saude Publica 2015, 49, 45. [CrossRef] [PubMed]

39. Batal, M.; Johnson-Down, L.; Moubarac, J.C.; Ing, A.; Fediuk, K.; Sadik, T.; Tikhonov, C.; Chan, L.; Willows, N. Quantifying associations of the dietary share of ultra-processed foods with overall diet quality in first nations peoples in the Canadian provinces of British Columbia, Alberta, Manitoba and Ontario. Public Health Nutr. 2017, 1-11. [CrossRef] [PubMed] 
40. Huh, I.S.; Kim, H.; Jo, H.K.; Lim, C.S.; Kim, J.S.; Kim, S.J.; Kwon, O.; Oh, B.; Chang, N. Instant noodle consumption is associated with cardiometabolic risk factors among college students in Seoul. Nutr. Res. Pract. 2017, 11, 232-239. [CrossRef] [PubMed]

41. Park, S.; Choi, H.S.; Bae, J.H. Instant noodles, processed food intake, and dietary pattern are associated with atopic dermatitis in an adult population (KNHANES 2009-2011). Asia Pac. J. Clin. Nutr. 2016, 25, 602-613. [PubMed]

42. Kim, S.Y.; Sim, S.; Park, B.; Kong, I.G.; Kim, J.H.; Choi, H.G. Dietary habits are associated with school performance in adolescents. Medicine 2016, 95, e3096. [CrossRef] [PubMed]

43. James, P.; Seward, M.W.; James O'Malley, A.; Subramanian, S.V.; Block, J.P. Changes in the food environment over time: Examining 40 years of data in the Framingham heart study. Int. J. Behav. Nutr. Phys. Act. 2017, 14, 84. [CrossRef] [PubMed]

44. Zenk, S.N.; Tarlov, E.; Powell, L.M. Weight and veterans' environments study (waves) I and II. Am. J. Health Promot. 2017, in press. [CrossRef]

45. Wang, Y.; Wang, L.; Xue, H.; Qu, W. A review of the growth of the fast food industry in China and its potential impact on obesity. Int. J. Environ. Res. Public Health 2016, 13, 1112. [CrossRef] [PubMed]

46. Keshari, P.; Mishra, C.P. Growing menace of fast food consumption in India: Time to act. Int. J. Community Med. Public Health 2017, 3, 1355-1362. [CrossRef]

47. Moayyed, H.; Kelly, B.; Feng, X.; Flood, V. Evaluation of a "healthiness" rating system for food outlet types in Australian residential communities. Nutr. Diet 2017, 74, 29-35. [CrossRef] [PubMed]

48. Lenk, K.M.; Caspi, C.E.; Harnack, L.; Laska, M.N. Customer characteristics and shopping patterns associated with healthy and unhealthy purchases at small and non-traditional food stores. J. Community Health 2017. [CrossRef] [PubMed]

49. Grech, A.; Hebden, L.; Roy, R.; Allman-Farinelli, M. Are products sold in university vending machines nutritionally poor? A food environment audit. Nutr. Diet 2017, 74, 185-190. [CrossRef] [PubMed]

50. Monroy-Parada, D.X.; Jacome-Gonzalez, M.L.; Moya-Geromini, M.A.; Rodriguez-Artalejo, F.; Royo-Bordonada, M.A. Adherence to nutritional recommendations in vending machines at secondary schools in Madrid (Spain), 2014-2015. Gac. Sanit. 2017. [CrossRef] [PubMed]

51. Gidney, C. "Nutritional wastelands": Vending machines, fast food outlets, and the fight over junk food in Canadian schools. Can. Bull. Med. Hist. 2015, 32, 391-409. [CrossRef] [PubMed]

52. Manyanga, T.; Tremblay, M.S.; Chaput, J.P.; Katzmarzyk, P.T.; Fogelholm, M.; Hu, G.; Kuriyan, R.; Kurpad, A.; Lambert, E.V.; Maher, C.; et al. Socioeconomic status and dietary patterns in children from around the world: Different associations by levels of country human development? BMC Public Health 2017, 17, 457. [CrossRef] [PubMed]

53. Gelenberg, A. Nutrition in psychiatry: We are what we eat? J. Clin. Psychiatry 1980, 41, 328-329. [PubMed]

54. O'Dea, J.A.; Mugridge, A.C. Nutritional quality of breakfast and physical activity independently predict the literacy and numeracy scores of children after adjusting for socioeconomic status. Health Educ. Res. 2012, 27, 975-985. [CrossRef] [PubMed]

55. Burrows, T.; Goldman, S.; Pursey, K.; Lim, R. Is there an association between dietary intake and academic achievement: A systematic review. J. Hum. Nutr. Diet 2017, 30, 117-140. [CrossRef] [PubMed]

56. Ptomey, L.T.; Steger, F.L.; Schubert, M.M.; Lee, J.; Willis, E.A.; Sullivan, D.K.; Szabo-Reed, A.N.; Washburn, R.A.; Donnelly, J.E. Breakfast intake and composition is associated with superior academic achievement in elementary schoolchildren. J. Am. Coll. Nutr. 2016, 35, 326-333. [CrossRef] [PubMed]

57. Anzman-Frasca, S.; Djang, H.C.; Halmo, M.M.; Dolan, P.R.; Economos, C.D. Estimating impacts of a breakfast in the classroom program on school outcomes. JAMA Pediatr. 2015, 169, 71-77. [CrossRef] [PubMed]

58. Young, H.; Benton, D. The effect of using isomaltulose (palatinose) to modulate the glycaemic properties of breakfast on the cognitive performance of children. Eur. J. Nutr. 2015, 54, 1013-1020. [CrossRef] [PubMed]

59. Benton, D.; Maconie, A.; Williams, C. The influence of the glycaemic load of breakfast on the behaviour of children in school. Physiol. Behav. 2007, 92, 717-724. [CrossRef] [PubMed]

60. Ingwersen, J.; Defeyter, M.A.; Kennedy, D.O.; Wesnes, K.A.; Scholey, A.B. A low glycaemic index breakfast cereal preferentially prevents children's cognitive performance from declining throughout the morning. Appetite 2007, 49, 240-244. [CrossRef] [PubMed] 
61. Attuquayefio, T.; Stevenson, R.J.; Oaten, M.J.; Francis, H.M. A four-day western-style dietary intervention causes reductions in hippocampal-dependent learning and memory and interoceptive sensitivity. PLoS ONE 2017, 12, e0172645. [CrossRef] [PubMed]

62. Lee, S.A.; Park, E.C.; Ju, Y.J.; Lee, T.H.; Han, E.; Kim, T.H. Breakfast consumption and depressive mood: A focus on socioeconomic status. Appetite 2017, 114, 313-319. [CrossRef] [PubMed]

63. Baron, R.; Mannien, J.; te Velde, S.J.; Klomp, T.; Hutton, E.K.; Brug, J. Socio-demographic inequalities across a range of health status indicators and health behaviours among pregnant women in prenatal primary care: A cross-sectional study. BMC Pregnancy Childbirth 2015, 15, 261. [CrossRef] [PubMed]

64. Lee, G.; Han, K.; Kim, H. Risk of mental health problems in adolescents skipping meals: The Korean national health and nutrition examination survey 2010 to 2012. Nurs. Outlook 2017, 65, 411-419. [CrossRef] [PubMed]

65. Li, Y.; Lv, M.R.; Wei, Y.J.; Sun, L.; Zhang, J.X.; Zhang, H.G.; Li, B. Dietary patterns and depression risk: A meta-analysis. Psychiatry Res. 2017, 253, 373-382. [CrossRef] [PubMed]

66. Cohen, J.F.; Gorski, M.T.; Gruber, S.A.; Kurdziel, L.B.; Rimm, E.B. The effect of healthy dietary consumption on executive cognitive functioning in children and adolescents: A systematic review. Br. J. Nutr. 2016, 116, 989-1000. [CrossRef] [PubMed]

67. Rios-Hernandez, A.; Alda, J.A.; Farran-Codina, A.; Ferreira-Garcia, E.; Izquierdo-Pulido, M. The mediterranean diet and adhd in children and adolescents. Pediatrics 2017, 139, e20162027. [CrossRef] [PubMed]

68. Jacka, F.N.; Cherbuin, N.; Anstey, K.J.; Sachdev, P.; Butterworth, P. Western diet is associated with a smaller hippocampus: A longitudinal investigation. BMC Med. 2015, 13, 215. [CrossRef] [PubMed]

69. Lee, J.; Pase, M.; Pipingas, A.; Raubenheimer, J.; Thurgood, M.; Villalon, L.; Macpherson, H.; Gibbs, A.; Scholey, A. Switching to a 10-day mediterranean-style diet improves mood and cardiovascular function in a controlled crossover study. Nutrition 2015, 31, 647-652. [CrossRef] [PubMed]

70. McMillan, L.; Owen, L.; Kras, M.; Scholey, A. Behavioural effects of a 10-day mediterranean diet. Results from a pilot study evaluating mood and cognitive performance. Appetite 2011, 56, 143-147. [CrossRef] [PubMed]

71. Steenbruggen, T.G.; Hoekstra, S.J.; van der Gaag, E.J. Could a change in diet revitalize children who suffer from unresolved fatigue? Nutrients 2015, 7, 1965-1977. [CrossRef] [PubMed]

72. Jacka, F.N.; O’Neil, A.; Opie, R.; Itsiopoulos, C.; Cotton, S.; Mohebbi, M.; Castle, D.; Dash, S.; Mihalopoulos, C.; Chatterton, M.L.; et al. A randomised controlled trial of dietary improvement for adults with major depression (the "smiles" trial). BMC Med. 2017, 15, 23. [CrossRef] [PubMed]

73. Breymeyer, K.L.; Lampe, J.W.; McGregor, B.A.; Neuhouser, M.L. Subjective mood and energy levels of healthy weight and overweight/obese healthy adults on high-and low-glycemic load experimental diets. Appetite 2016, 107, 253-259. [CrossRef] [PubMed]

74. Simopoulos, A.P.; DiNicolantonio, J.J. The importance of a balanced omega- 6 to omega- 3 ratio in the prevention and management of obesity. Open Heart 2016, 3, e000385. [CrossRef] [PubMed]

75. Simopoulos, A.P. An increase in the omega-6/omega-3 fatty acid ratio increases the risk for obesity. Nutrients 2016, 8, 128. [CrossRef] [PubMed]

76. Grant, R.; Guest, J. Role of omega-3 pufas in neurobiological health. Adv. Neurobiol. 2016, 12, $247-274$. [PubMed]

77. Husted, K.S.; Bouzinova, E.V. The importance of n-6/n-3 fatty acids ratio in the major depressive disorder. Medicina 2016, 52, 139-147. [CrossRef] [PubMed]

78. Parletta, N.; Niyonsenga, T.; Duff, J. Omega-3 and omega-6 polyunsaturated fatty acid levels and correlations with symptoms in children with attention deficit hyperactivity disorder, autistic spectrum disorder and typically developing controls. PLoS ONE 2016, 11, e0156432. [CrossRef] [PubMed]

79. Knuppel, A.; Shipley, M.J.; Llewellyn, C.H.; Brunner, E.J. Sugar intake from sweet food and beverages, common mental disorder and depression: Prospective findings from the whitehall II study. Sci. Rep. 2017, 7, 6287. [CrossRef] [PubMed]

80. Wiss, D.A.; Criscitelli, K.; Gold, M.; Avena, N. Preclinical evidence for the addiction potential of highly palatable foods: Current developments related to maternal influence. Appetite 2017, 115, 19-27. [CrossRef] [PubMed] 
81. Yu, C.J.; Du, J.C.; Chiou, H.C.; Feng, C.C.; Chung, M.Y.; Yang, W.; Chen, Y.S.; Chien, L.C.; Hwang, B.; Chen, M.L. Sugar-sweetened beverage consumption is adversely associated with childhood attention deficit/hyperactivity disorder. Int. J. Environ. Res. Public Health 2016, 13, E678. [CrossRef] [PubMed]

82. Tenk, C.M.; Felfeli, T. Sucrose and fat content significantly affects palatable food consumption in adolescent male and female rats. Appetite 2017, 118, 49-59. [CrossRef] [PubMed]

83. Rakosky, J. Soy products for the meat industry. J. Agric. Food Chem. 1970, 18, 1005-1009. [CrossRef]

84. McCloud, J.T. Soy protein in school feeding programs. J. Am. Oil Chem. Soc. 1974, 51, 141A. [CrossRef]

85. Cassidy, A.; Brown, J.E.; Hawdon, A.; Faughnan, M.S.; King, L.J.; Millward, J.; Zimmer-Nechemias, L.; Wolfe, B.; Setchell, K.D. Factors affecting the bioavailability of soy isoflavones in humans after ingestion of physiologically relevant levels from different soy foods. J. Nutr. 2006, 136, 45-51. [PubMed]

86. Rakosky, J. Soy protein in foods: Their use and regulations in the U.S. J. Am. Oil Chem. Soc. 1975, 52, 272a-274a. [CrossRef] [PubMed]

87. Hartley, D.E.; Edwards, J.E.; Spiller, C.E.; Alom, N.; Tucci, S.; Seth, P.; Forsling, M.L.; File, S.E. The soya isoflavone content of rat diet can increase anxiety and stress hormone release in the male rat. Psychopharmacology 2003, 167, 46-53. [CrossRef] [PubMed]

88. Patisaul, H.B.; Blum, A.; Luskin, J.R.; Wilson, M.E. Dietary soy supplements produce opposite effects on anxiety in intact male and female rats in the elevated plus-maze. Behav. Neurosci. 2005, 119, 587-594. [CrossRef] [PubMed]

89. Yu, B.; Yu, F.; Su, Q.; Zhang, Q.; Liu, L.; Meng, G.; Wu, H.; Xia, Y.; Bao, X.; Shi, H.; et al. A j-shaped association between soy food intake and depressive symptoms in Chinese adults. Clin. Nutr. 2017. [CrossRef] [PubMed]

90. Uribarri, J.; Woodruff, S.; Goodman, S.; Cai, W.; Chen, X.; Pyzik, R.; Yong, A.; Striker, G.E.; Vlassara, H. Advanced glycation end products in foods and a practical guide to their reduction in the diet. J. Am. Diet Assoc. 2010, 110, 911-916. [CrossRef] [PubMed]

91. Saha, A.; Poojary, P.; Chan, L.; Chauhan, K.; Nadkarni, G.; Coca, S.; Uribarri, J. Increased odds of metabolic syndrome with consumption of high dietary advanced glycation end products in adolescents. Diabetes Metab. 2017. [CrossRef] [PubMed]

92. Aragno, M.; Mastrocola, R. Dietary sugars and endogenous formation of advanced glycation endproducts: Emerging mechanisms of disease. Nutrients 2017, 9, E385. [CrossRef] [PubMed]

93. Smith, P.K. Do advanced glycation end-products cause food allergy? Curr. Opin. Allergy Clin. Immunol. 2017. [CrossRef] [PubMed]

94. Prasad, K.; Tiwari, S. Therapeutic interventions for advanced glycation-end products and its receptormediated cardiovascular disease. Curr. Pharm. Des. 2017, 23, 937-943. [CrossRef] [PubMed]

95. Stevens, L.J.; Burgess, J.R.; Stochelski, M.A.; Kuczek, T. Amounts of artificial food dyes and added sugars in foods and sweets commonly consumed by children. Clin. Pediatr. 2015, 54, 309-321. [CrossRef] [PubMed]

96. Raposa, B.; Ponusz, R.; Gerencser, G.; Budan, F.; Gyongyi, Z.; Tibold, A.; Hegyi, D.; Kiss, I.; Koller, A.; Varjas, T. Food additives: Sodium benzoate, potassium sorbate, azorubine, and tartrazine modify the expression of nfkappab, gadd45alpha, and mapk8 genes. Physiol. Int. 2016, 103, 334-343. [CrossRef] [PubMed]

97. Stevens, L.J.; Kuczek, T.; Burgess, J.R.; Stochelski, M.A.; Arnold, L.E.; Galland, L. Mechanisms of behavioral, atopic, and other reactions to artificial food colors in children. Nutr. Rev. 2013, 71, 268-281. [CrossRef] [PubMed]

98. Batada, A.; Jacobson, M.F. Prevalence of artificial food colors in grocery store products marketed to children. Clin. Pediatr. 2016, 55, 1113-1119. [CrossRef] [PubMed]

99. Buka, I.; Osornio-Vargas, A.; Clark, B. Food additives, essential nutrients and neurodevelopmental behavioural disorders in children: A brief review. Paediatr. Child Health 2011, 16, e54-e56. [PubMed]

100. Gibson, R. Too skinny a burger is a mighty hard sell Mcdonald's learns. The Wall Street Journal, 4 April 1993, p. 1 A.

101. Martino, J.V.; Van Limbergen, J.; Cahill, L.E. The role of carrageenan and carboxymethylcellulose in the development of intestinal inflammation. Front. Pediatr. 2017, 5, 96. [CrossRef] [PubMed]

102. Prescott, S.L. History of medicine: Origin of the term microbiome and why it matters. Hum. Microbiome J. 2017, 4, 24-25. [CrossRef]

103. Dubos, R. Lasting biological effects of early influences. Perspect. Biol. Med. 1969, 12, 479-491. [CrossRef] [PubMed] 
104. Dubos, R.; Savage, D.; Schaedler, R. Biological freudianism. Lasting effects of early environmental influences. Pediatrics 1966, 38, 789-800. [PubMed]

105. Petersen, C.; Round, J.L. Defining dysbiosis and its influence on host immunity and disease. Cell Microbiol. 2014, 16, 1024-1033. [CrossRef] [PubMed]

106. Ridaura, V.K.; Faith, J.J.; Rey, F.E.; Cheng, J.; Duncan, A.E.; Kau, A.L.; Griffin, N.W.; Lombard, V.; Henrissat, B.; Bain, J.R.; et al. Gut microbiota from twins discordant for obesity modulate metabolism in mice. Science 2013, 341, 1241214. [CrossRef] [PubMed]

107. De Palma, G.; Lynch, M.D.; Lu, J.; Dang, V.T.; Deng, Y.; Jury, J.; Umeh, G.; Miranda, P.M.; Pigrau Pastor, M.; Sidani, S.; et al. Transplantation of fecal microbiota from patients with irritable bowel syndrome alters gut function and behavior in recipient mice. Sci. Transl. Med. 2017, 9. [CrossRef] [PubMed]

108. Kelly, J.R.; Borre, Y.; O’Brien, C.; Patterson, E.; El Aidy, S.; Deane, J.; Kennedy, P.J.; Beers, S.; Scott, K.; Moloney, G.; et al. Transferring the blues: Depression-associated gut microbiota induces neurobehavioural changes in the rat. J. Psychiatr. Res. 2016, 82, 109-118. [CrossRef] [PubMed]

109. Gupta, V.K.; Paul, S.; Dutta, C. Geography, ethnicity or subsistence-specific variations in human microbiome composition and diversity. Front. Microbiol. 2017, 8, 1162. [CrossRef] [PubMed]

110. Segata, N. Gut microbiome: Westernization and the disappearance of intestinal diversity. Curr. Biol. 2015, 25, R611-R613. [CrossRef] [PubMed]

111. Thaiss, C.A.; Itav, S.; Rothschild, D.; Meijer, M.; Levy, M.; Moresi, C.; Dohnalova, L.; Braverman, S.; Rozin, S.; Malitsky, S.; et al. Persistent microbiome alterations modulate the rate of post-dieting weight regain. Nature 2016. [CrossRef] [PubMed]

112. Kina-Tanada, M.; Sakanashi, M.; Tanimoto, A.; Kaname, T.; Matsuzaki, T.; Noguchi, K.; Uchida, T.; Nakasone, J.; Kozuka, C.; Ishida, M.; et al. Long-term dietary nitrite and nitrate deficiency causes the metabolic syndrome, endothelial dysfunction and cardiovascular death in mice. Diabetologia 2017, 60, 1138-1151. [CrossRef] [PubMed]

113. Sonnenburg, E.D.; Smits, S.A.; Tikhonov, M.; Higginbottom, S.K.; Wingreen, N.S.; Sonnenburg, J.L. Diet-induced extinctions in the gut microbiota compound over generations. Nature 2016, 529, $212-215$. [CrossRef] [PubMed]

114. Noble, E.E.; Hsu, T.M.; Jones, R.B.; Fodor, A.A.; Goran, M.I.; Kanoski, S.E. Early-life sugar consumption affects the rat microbiome independently of obesity. J. Nutr. 2017, 147, 20-28. [CrossRef] [PubMed]

115. Qu, W.; Yuan, X.; Zhao, J.; Zhang, Y.; Hu, J.; Wang, J.; Li, J. Dietary advanced glycation end products modify gut microbial composition and partially increase colon permeability in rats. Mol. Nutr. Food Res. 2017. [CrossRef] [PubMed]

116. Chassaing, B.; Van de Wiele, T.; De Bodt, J.; Marzorati, M.; Gewirtz, A.T. Dietary emulsifiers directly alter human microbiota composition and gene expression ex vivo potentiating intestinal inflammation. Gut 2017, 66, 1414-1427. [CrossRef] [PubMed]

117. Singh, R.K.; Wheildon, N.; Ishikawa, S. Food additive p-80 impacts mouse gut microbiota promoting intestinal inflammation, obesity and liver dysfunction. SOJ Microbiol. Infect. Dis. 2016, 4. [CrossRef] [PubMed]

118. Viennois, E.; Merlin, D.; Gewirtz, A.T.; Chassaing, B. Dietary emulsifier-induced low-grade inflammation promotes colon carcinogenesis. Cancer Res. 2017, 77, 27-40. [CrossRef] [PubMed]

119. Kaliannan, K.; Wang, B.; Li, X.Y.; Kim, K.J.; Kang, J.X. A host-microbiome interaction mediates the opposing effects of omega-6 and omega-3 fatty acids on metabolic endotoxemia. Sci. Rep. 2015, 5, 11276. [CrossRef] [PubMed]

120. Zhu, Y.; Shi, X.; Lin, X.; Ye, K.; Xu, X.; Li, C.; Zhou, G. Beef, chicken, and soy proteins in diets induce different gut microbiota and metabolites in rats. Front. Microbiol. 2017, 8, 1395. [CrossRef] [PubMed]

121. Shang, Q.; Sun, W.; Shan, X.; Jiang, H.; Cai, C.; Hao, J.; Li, G.; Yu, G. Carrageenan-induced colitis is associated with decreased population of anti-inflammatory bacterium, akkermansia muciniphila, in the gut microbiota of c57bl/6j mice. Toxicol. Lett. 2017, 279, 87-95. [CrossRef] [PubMed]

122. Henning, S.M.; Yang, J.; Shao, P.; Lee, R.P.; Huang, J.; Ly, A.; Hsu, M.; Lu, Q.Y.; Thames, G.; Heber, D.; et al. Health benefit of vegetable/fruit juice-based diet: Role of microbiome. Sci. Rep. 2017, 7, 2167. [CrossRef] [PubMed]

123. Lawrence, K.; Hyde, J. Microbiome restoration diet improves digestion, cognition and physical and emotional wellbeing. PLoS ONE 2017, 12, e0179017. [CrossRef] [PubMed] 
124. Wallace, C.J.K.; Milev, R. The effects of probiotics on depressive symptoms in humans: A systematic review. Ann. Gen. Psychiatry 2017, 16, 14. [CrossRef] [PubMed]

125. Schmidt, K.; Cowen, P.J.; Harmer, C.J.; Tzortzis, G.; Errington, S.; Burnet, P.W. Prebiotic intake reduces the waking cortisol response and alters emotional bias in healthy volunteers. Psychopharmacology 2015, 232, 1793-1801. [CrossRef] [PubMed]

126. Nishida, K.; Sawada, D.; Kuwano, Y.; Sugawara, T.; Aoki, Y.; Fujiwara, S.; Rokutan, K. Daily administration of paraprobiotic lactobacillus gasseri cp2305 ameliorates chronic stress-associated symptoms in Japanese medical students. J. Funct. Food 2017, 36, 112-121. [CrossRef]

127. Ohsawa, K.; Nakamura, F.; Uchida, N.; Mizuno, S.; Yokogoshi, H. Lactobacillus helveticus-fermented milk containing lactononadecapeptide (nippltqtpvvvppflqpe) improves cognitive function in healthy middle-aged adults: A randomised, double-blind, placebo-controlled trial. Int. J. Food Sci. Nutr. 2017, 1-8. [CrossRef] [PubMed]

128. Noble, E.E.; Hsu, T.M.; Kanoski, S.E. Gut to brain dysbiosis: Mechanisms linking western diet consumption, the microbiome, and cognitive impairment. Front. Behav. Neurosci. 2017, 11, 9. [CrossRef] [PubMed]

129. Cepeda, M.S.; Katz, E.G.; Blacketer, C. Microbiome-gut-brain axis: Probiotics and their association with depression. J. Neuropsychiatry Clin. Neurosci. 2017, 29, 39-44. [CrossRef] [PubMed]

130. Soga, M.; Gaston, K.J. Extinction of experience: The loss of human-nature interactions. Front. Ecol. Environ. 2016, 14, 94-101. [CrossRef]

131. Soga, M.; Gaston, K.J.; Yamaura, Y.; Kurisu, K.; Hanaki, K. Both direct and vicarious experiences of nature affect children's willingness to conserve biodiversity. Int. J. Environ. Res. Public Health 2016, 13. [CrossRef] [PubMed]

132. Lumber, R.; Richardson, M.; Sheffield, D. Beyond knowing nature: Contact, emotion, compassion, meaning, and beauty are pathways to nature connection. PLoS ONE 2017, 12, e0177186. [CrossRef] [PubMed]

133. Capaldi, C.A.; Dopko, R.L.; Zelenski, J.M. The relationship between nature connectedness and happiness: A meta-analysis. Front. Psychol. 2014, 5, 976. [CrossRef] [PubMed]

134. Nury, E.; Sarti, A.; Dijkstra, C.; Seidell, J.C.; Dedding, C. Sowing seeds for healthier diets: Children's perspectives on school gardening. Int. J. Environ. Res. Public Health 2017, 14, E688. [CrossRef] [PubMed]

135. Alaimo, K.; Beavers, A.W.; Crawford, C.; Snyder, E.H.; Litt, J.S. Amplifying health through community gardens: A framework for advancing multicomponent, behaviorally based neighborhood interventions. Curr. Environ. Health Rep. 2016, 3, 302-312. [CrossRef] [PubMed]

136. Soga, M.; Gaston, K.J.; Yamaura, Y. Gardening is beneficial for health: A meta-analysis. Prev. Med. Rep. 2017, 5, 92-99. [CrossRef] [PubMed]

137. Utter, J.; Denny, S.; Dyson, B. School gardens and adolescent nutrition and BMI: Results from a national, multilevel study. Prev. Med. 2016, 83, 1-4. [CrossRef] [PubMed]

138. Brown, J.D.; Colson, G.; de La Serre, C.B.; Magnan, N. Summer garden programs improve children's food knowledge and preferences: Evidence using stated and revealed preference measures. Horttechnology 2016, $26,133-140$.

139. Zwerdling, D. Free breakfasts fatten snack food industry. Capital Journal, 20 November 1972, p. 5.

140. Basch, C.H.; Hammond, R.; Ethan, D.; Samuel, L. Food advertisements in two popular U.S. Parenting magazines: Results of a five-year analysis. Glob. J. Health Sci. 2013, 6, 175-182. [CrossRef] [PubMed]

141. LoDolce, M.E.; Harris, J.L.; Schwartz, M.B. Sugar as part of a balanced breakfast? What cereal advertisements teach children about healthy eating. J. Health Commun. 2013, 18, 1293-1309. [CrossRef] [PubMed]

142. Cohen, D.A.; Babey, S.H. Contextual influences on eating behaviours: Heuristic processing and dietary choices. Obes. Rev. 2012, 13, 766-779. [CrossRef] [PubMed]

143. Longacre, M.R.; Drake, K.M.; Titus, L.J.; Harris, J.; Cleveland, L.P.; Langeloh, G.; Hendricks, K.; Dalton, M.A. Child-targeted TV advertising and preschoolers' consumption of high-sugar breakfast cereals. Appetite 2017, 108, 295-302. [CrossRef] [PubMed]

144. Dalton, M.A.; Longacre, M.R.; Drake, K.M.; Cleveland, L.P.; Harris, J.L.; Hendricks, K.; Titus, L.J. Child-targeted fast-food television advertising exposure is linked with fast-food intake among pre-school children. Public Health Nutr. 2017, 20, 1548-1556. [CrossRef] [PubMed]

145. Norman, J.; Kelly, B.; Boyland, E.; McMahon, A.T. The impact of marketing and advertising on food behaviours: Evaluating the evidence for a causal relationship. Curr. Nutr. Rep. 2016, 5, 139. [CrossRef] 
146. Dykstra, H.; Davey, A.; Fisher, J.O.; Polonsky, H.; Sherman, S.; Abel, M.L.; Dale, L.C.; Foster, G.D.; Bauer, K.W. Breakfast-skipping and selecting low-nutritional-quality foods for breakfast are common among low-income urban children, regardless of food security status. J. Nutr. 2016, 146, 630-636. [CrossRef] [PubMed]

147. Ortiz, S.E.; Zimmerman, F.J.; Adler, G.J., Jr. Increasing public support for food-industry related, obesity prevention policies: The role of a taste-engineering frame and contextualized values. Soc. Sci. Med. 2016, 156, 142-153. [CrossRef] [PubMed]

148. Glasgow, S.; Schrecker, T. The double burden of neoliberalism? Noncommunicable disease policies and the global political economy of risk. Health Place 2016, 39, 204-211. [CrossRef] [PubMed]

149. Brijnath, B.; Antoniades, J. "I'm running my depression:" Self-management of depression in neoliberal Australia. Soc. Sci. Med. 2016, 152, 1-8. [CrossRef] [PubMed]

150. Davies, J. Political pills: Psychopharmaceuticals and neoliberalism as mutually supporting. In The Sedated Society; Davies, J., Ed.; Springer: Cham, Switzerland, 2017; pp. 189-225.

151. Clapp, J.; Scrinis, G. Big food, nutritionism, and corporate power. Globalizations 2017, 14, 578-595. [CrossRef]

152. Leon, K.S.; Ken, I. Food fraud and the partnership for a "healthier" America: A case study in state-corporate crime. Crit. Criminol. 2017, in press. [CrossRef]

153. Aaron, D.G.; Siegel, M.B. Sponsorship of national health organizations by two major soda companies. Am. J. Prev. Med. 2016. [CrossRef] [PubMed]

154. Renz, H.; Holt, P.G.; Inouye, M.; Logan, A.C.; Prescott, S.L.; Sly, P.D. An exposome perspective: Early-life events and immune development in a changing world. J. Allergy Clin. Immunol. 2017, 140, 24-40. [CrossRef] [PubMed]

155. Allen, J.; Balfour, R.; Bell, R.; Marmot, M. Social determinants of mental health. Int. Rev. Psychiatry 2014, 26, 392-407. [CrossRef] [PubMed]

156. Roberts, J; Donkin, A; Marmot, M. Opportunities for reducing socioeconomic inequalities in the mental health of children and young people-Reducing adversity and increasing resilience. J. Public Ment. Health 2016, 15, 4-17. [CrossRef]

157. Pickett, K.E.; Wilkinson, R.G. Inequality: An underacknowledged source of mental illness and distress. Br. J. Psychiatry 2010, 197, 426-428. [CrossRef] [PubMed]

158. Tiikkaja, S.; Sandin, S.; Hultman, C.M.; Modin, B.; Malki, N.; Sparen, P. Psychiatric disorder and work life: A longitudinal study of intra-generational social mobility. Int. J. Soc. Psychiatry 2016, 62, 156-166. [CrossRef] [PubMed]

159. Fuller-Thomson, E.; Agbeyaka, S.; LaFond, D.M.; Bern-Klug, M. Flourishing after depression: Factors associated with achieving complete mental health among those with a history of depression. Psychiatry Res. 2016, 242, 111-120. [CrossRef] [PubMed]

160. Russell, S.J.; Hughes, K.; Bellis, M.A. Impact of childhood experience and adult well-being on eating preferences and behaviours. BMJ Open 2016, 6. [CrossRef] [PubMed]

161. Prescott, S.L.; Logan, A.C. Transforming life: A broad view of the developmental origins of health and disease concept from an ecological justice perspective. Int. J. Environ. Res. Public Health 2016, 13, E1075. [CrossRef] [PubMed]

162. Logan, A.C. Dysbiotic drift: Mental health, environmental grey space, and microbiota. J. Physiol. Anthropol. 2015, 34, 23. [CrossRef] [PubMed]

163. Fraga, S.; Marques-Vidal, P.; Vollenweider, P.; Waeber, G.; Guessous, I.; Paccaud, F.; Barros, H.; Stringhini, S. Association of socioeconomic status with inflammatory markers: A two cohort comparison. Prev. Med. 2015, 71, 12-19. [CrossRef] [PubMed]

164. Stringhini, S.; Batty, G.D.; Bovet, P.; Shipley, M.J.; Marmot, M.G.; Kumari, M.; Tabak, A.G.; Kivimaki, M. Association of lifecourse socioeconomic status with chronic inflammation and type 2 diabetes risk: The Whitehall II prospective cohort study. PLoS Med. 2013, 10, e1001479. [CrossRef] [PubMed]

165. Keita, A.D.; Judd, S.E.; Howard, V.J.; Carson, A.P.; Ard, J.D.; Fernandez, J.R. Associations of neighborhood area level deprivation with the metabolic syndrome and inflammation among middle- and older-age adults. BMC Public Health 2014, 14, 1319. [CrossRef] [PubMed]

166. Nazmi, A.; Diez Roux, A.; Ranjit, N.; Seeman, T.E.; Jenny, N.S. Cross-sectional and longitudinal associations of neighborhood characteristics with inflammatory markers: Findings from the multi-ethnic study of atherosclerosis. Health Place 2010, 16, 1104-1112. [CrossRef] [PubMed] 
167. Brody, G.H.; Lei, M.K.; Chen, E.; Miller, G.E. Neighborhood poverty and allostatic load in African American youth. Pediatrics 2014, 134, E1362-E1368. [CrossRef] [PubMed]

168. Gianaros, P.J.; Kuan, D.C.; Marsland, A.L.; Sheu, L.K.; Hackman, D.A.; Miller, K.G.; Manuck, S.B. Community socioeconomic disadvantage in midlife relates to cortical morphology via neuroendocrine and cardiometabolic pathways. Cereb. Cortex 2017, 27, 460-473. [CrossRef] [PubMed]

169. Bird, C.E.; Seeman, T.; Escarce, J.J.; Basurto-Davila, R.; Finch, B.K.; Dubowitz, T.; Heron, M.; Hale, L.; Merkin, S.S.; Weden, M.; et al. Neighbourhood socioeconomic status and biological "wear and tear" in a nationally representative sample of U.S. adults. J. Epidemiol. Community Health 2010, 64, 860-865. [CrossRef] [PubMed]

170. Schulz, A.J.; Mentz, G.; Lachance, L.; Zenk, S.N.; Johnson, J.; Stokes, C.; Mandell, R. Do observed or perceived characteristics of the neighborhood environment mediate associations between neighborhood poverty and cumulative biological risk? Health Place 2013, 24, 147-156. [CrossRef] [PubMed]

171. Theall, K.P.; Drury, S.S.; Shirtcliff, E.A. Cumulative neighborhood risk of psychosocial stress and allostatic load in adolescents. Am. J. Epidemiol. 2012, 176, S164-S174. [CrossRef] [PubMed]

172. Nicklett, E.J.; Szanton, S.; Sun, K.; Ferrucci, L.; Fried, L.P.; Guralnik, J.M.; Semba, R.D. Neighborhood socioeconomic status is associated with serum carotenoid concentrations in older, community-dwelling women. J. Nutr. 2011, 141, 284-289. [CrossRef] [PubMed]

173. Stimpson, J.P.; Nash, A.C.; Ju, H.; Eschbach, K. Neighborhood deprivation is associated with lower levels of serum carotenoids among adults participating in the third national health and nutrition examination survey. J. Am. Diet Assoc. 2007, 107, 1895-1902. [CrossRef] [PubMed]

174. Wrieden, W.L.; Hannah, M.K.; Bolton-Smith, C.; Tavendale, R.; Morrison, C.; Tunstall-Pedoe, H. Plasma vitamin $\mathrm{C}$ and food choice in the third Glasgow Monica population survey. J. Epidemiol. Community Health 2000, 54, 355-360. [CrossRef] [PubMed]

175. Shohaimi, S.; Bingham, S.; Welch, A.; Luben, R.; Day, N.; Wareham, N.; Khaw, K.T. Occupational social class, educational level and area deprivation independently predict plasma ascorbic acid concentration: A cross-sectional population based study in the norfolk cohort of the european prospective investigation into cancer (epic-norfolk). Eur. J. Clin. Nutr. 2004, 58, 1432-1435. [CrossRef] [PubMed]

176. Kristenson, M.; Kucinskiene, Z.; Bergdahl, B.; Orth-Gomer, K. Risk factors for coronary heart disease in different socioeconomic groups of Lithuania and Sweden-The LIVICORDIA study. Scand. J. Public Health 2001, 29, 140-150. [CrossRef] [PubMed]

177. Ganji, V.; Kafai, M.R. Population determinants of serum lycopene concentrations in the United States: Data from the third national health and nutrition examination survey, 1988-1994. J. Nutr. 2005, 135, 567-572. [PubMed]

178. Janicki-Deverts, D.; Cohen, S.; Matthews, K.A.; Gross, M.D.; Jacobs, D.R., Jr. Socioeconomic status, antioxidant micronutrients, and correlates of oxidative damage: The coronary artery risk development in young adults (Cardia) study. Psychosom. Med. 2009, 71, 541-548. [CrossRef] [PubMed]

179. Miller, G.E.; Engen, P.A.; Gillevet, P.M.; Shaikh, M.; Sikaroodi, M.; Forsyth, C.B.; Mutlu, E.; Keshavarzian, A. Lower neighborhood socioeconomic status associated with reduced diversity of the colonic microbiota in healthy adults. PLoS ONE 2016, 11, e0148952. [CrossRef] [PubMed]

180. Craigie, A.M.; Lake, A.A.; Kelly, S.A.; Adamson, A.J.; Mathers, J.C. Tracking of obesity-related behaviours from childhood to adulthood: A systematic review. Maturitas 2011, 70, 266-284. [CrossRef] [PubMed]

181. Bivens, G.J. Poverty? Malnutrition? Even hunger? The white house takes a look. J. Consum. Aff. 1970, 4, 59-64. [CrossRef]

182. U.S. Government Printing Office. Task force action statement. In Proceedings of the White House Conference on Food Nutrition and Health, Washington, DC, USA, 2-4 December 1969; U.S. Government Printing Office: Washington, DC, USA, 1969; pp. 302-305.

183. Rodriguez, L.A.; Madsen, K.A.; Cotterman, C.; Lustig, R.H. Added sugar intake and metabolic syndrome in U.S. adolescents: Cross-sectional analysis of the national health and nutrition examination survey 2005-2012. Public Health Nutr. 2016, 19, 2424-2434. [CrossRef] [PubMed]

184. Heid, M. Experts Say Lobbying Skewed the us Dietary Guidelines. Time, 8 January 2016. Available online: http:/ / time.com/4130043/lobbying-politics-dietary-guidelines/ (accessed on 19 August 2017).

185. Cheon, B.K.; Hong, Y.Y. Mere experience of low subjective socioeconomic status stimulates appetite and food intake. Proc. Natl. Acad. Sci. USA 2017, 114, 72-77. [CrossRef] [PubMed] 
186. Bratanova, B.; Loughnan, S.; Klein, O.; Claassen, A.; Wood, R. Poverty, inequality, and increased consumption of high calorie food: Experimental evidence for a causal link. Appetite 2016, 100, 162-171. [CrossRef] [PubMed]

187. Cardel, M.I.; Johnson, S.L.; Beck, J.; Dhurandhar, E.; Keita, A.D.; Tomczik, A.C.; Pavela, G.; Huo, T.; Janicke, D.M.; Muller, K.; et al. The effects of experimentally manipulated social status on acute eating behavior: A randomized, crossover pilot study. Physiol. Behav. 2016, 162, 93-101. [CrossRef] [PubMed]

188. Giurgescu, C.; Engeland, C.G.; Templin, T.N.; Zenk, S.N.; Koenig, M.D.; Garfield, L. Racial discrimination predicts greater systemic inflammation in pregnant African American women. Appl. Nurs. Res. 2016, 32, 98-103. [CrossRef] [PubMed]

189. Beatty, D.L.; Matthews, K.A.; Bromberger, J.T.; Brown, C. Everyday discrimination prospectively predicts inflammation across 7-years in racially diverse midlife women: Study of women's health across the nation. J. Soc. Issues 2014, 70, 298-314. [CrossRef] [PubMed]

190. Lewis, T.T.; Aiello, A.E.; Leurgans, S.; Kelly, J.; Barnes, L.L. Self-reported experiences of everyday discrimination are associated with elevated c-reactive protein levels in older African-American adults. Brain Behav. Immun. 2010, 24, 438-443. [CrossRef] [PubMed]

191. Reeves, A.; McKee, M.; Mackenbach, J.; Whitehead, M.; Stuckler, D. Introduction of a national minimum wage reduced depressive symptoms in low-wage workers: A quasi-natural experiment in the UK. Health Econ. 2016. [CrossRef] [PubMed]

192. Burmaster, K.B.; Landefeld, J.C.; Rehkopf, D.H.; Lahiff, M.; Sokal-Gutierrez, K.; Adler-Milstein, S.; Fernald, L.C. Impact of a private sector living wage intervention on depressive symptoms among apparel workers in the Dominican Republic: A quasi-experimental study. BMJ Open 2015, 5, e007336. [PubMed]

193. Lenhart, O. Do higher minimum wages benefit health? Evidence from the UK. J. Policy Anal. Manag. 2017, in press. [CrossRef]

194. Lenhart, O. The impact of minimum wages on population health: Evidence from 24 OECD countries. Eur. J. Health Econ. 2016. [CrossRef] [PubMed]

195. Ponce, N.; Shimkhada, R.; Raub, A.; Daoud, A.; Nandi, A.; Richter, L.; Heymann, J. The association of minimum wage change on child nutritional status in Lmics: A quasi-experimental multi-country study. Glob. Public Health 2017, 1-15. [CrossRef] [PubMed]

196. Reeves, A.; Loopstra, R.; Stuckler, D. The growing disconnect between food prices and wages in Europe: Cross-national analysis of food deprivation and welfare regimes in twenty-one EU countries, 2004-2012. Public Health Nutr. 2017, 20, 1414-1422. [CrossRef] [PubMed]

197. Dickman, S.L.; Himmelstein, D.U.; Woolhandler, S. Inequality and the health-care system in the USA. Lancet 2017, 389, 1431-1441. [CrossRef]

198. Whalen, K.A.; Judd, S.; McCullough, M.L.; Flanders, W.D.; Hartman, T.J.; Bostick, R.M. Paleolithic and mediterranean diet pattern scores are inversely associated with all-cause and cause-specific mortality in adults. J. Nutr. 2017, 147, 612-620. [CrossRef] [PubMed]

199. Albuquerque, G.; Moreira, P.I.; Rosario, R.; Araujo, A.; Teixeira, V.H.; Lopes, O.; Moreira, A.; Padrao, P. Adherence to the mediterranean diet in children: Is it associated with economic cost? Porto Biomed. J. 2017, 2, 115-119. [CrossRef]

200. Genoni, A.; Lo, J.; Lyons-Wall, P.; Devine, A. Compliance, palatability and feasibility of paleolithic and Australian guide to healthy eating diets in healthy women: A 4-week dietary intervention. Nutrients 2016, 8, E481. [CrossRef] [PubMed]

201. Bonaccio, M.; Di Castelnuovo, A.; Pounis, G.; Costanzo, S.; Persichillo, M.; Cerletti, C.; Donati, M.B.; de Gaetano, G.; Iacoviello, L.; Investigators, M.-S.P. High adherence to the mediterranean diet is associated with cardiovascular protection in higher but not in lower socioeconomic groups: Prospective findings from the Moli-Sani study. Int. J. Epidemiol. 2017, in press.

202. Bhatia, R.; Gaydos, M.; Yu, K.; Weintraub, J. Protecting labor rights: Roles for public health. Public Health Rep. 2013, 128, 39-47. [CrossRef] [PubMed]

203. Houghton, F. The prevention paradox mark II: An appeal for diversity in public health. J. Public Health 2016. [CrossRef]

204. Korkery, M.; Protess, B. How the twinkie made the superrich even richer. New York Times, 11 December 2016, p. A1.

205. Bromwich, J.E. The playboy mansion has a buyer-The twinkie king. New York Times, 8 June 2016, p. B2. 
206. Lewis, L.B.; Sloane, D.C.; Nascimento, L.M.; Diamant, A.L.; Guinyard, J.J.; Yancey, A.K.; Flynn, G.; REACH Coalition of the African Americans Building a Legacy of Health Project. African Americans' access to healthy food options in south Los Angeles restaurants. Am. J. Public Health 2005, 95, 668-673. [CrossRef] [PubMed]

207. Robles, B.; Kuo, T. Predictors of public support for nutrition-focused policy, systems and environmental change strategies in Los Angeles county, 2013. BMJ Open 2017, 7, e012654. [CrossRef] [PubMed]

208. Severson, K. Los Angeles stages a fast food intervention. New York Times, 12 August 2008, p. F1.

209. Bryan, C.J.; Yeager, D.S.; Hinojosa, C.P.; Chabot, A.; Bergen, H.; Kawamura, M.; Steubing, F. Harnessing adolescent values to motivate healthier eating. Proc. Natl. Acad. Sci. USA 2016, 113, 10830-10835. [CrossRef] [PubMed]

210. Thompson, B.; Molina, Y.; Viswanath, K.; Warnecke, R.; Prelip, M.L. Strategies to empower communities to reduce health disparities. Health Aff. 2016, 35, 1424-1428. [CrossRef] [PubMed]

211. Gardner, C.D.; Hauser, M.E. Food revolution. Am. J. Lifestyle Med. 2017. [CrossRef]

212. Yancey, A.K.; Cole, B.L.; Brown, R.; Williams, J.D.; Hillier, A.; Kline, R.S.; Ashe, M.; Grier, S.A.; Backman, D.; McCarthy, W.J. A cross-sectional prevalence study of ethnically targeted and general audience outdoor obesity-related advertising. Milbank Q. 2009, 87, 155-184. [CrossRef] [PubMed]

213. Prescott, S.L.; Logan, A.C. Down to earth: Planetary health and biophilosophy in the symbiocene epoch. Challenges 2017, 8, 19. [CrossRef]

214. Green, E.L.; Hirschfeld Davis, J. Trump takes aim at school lunch guidelines and a girls' education program. New York Times, 2 May 2017, p. A17.

215. Burrows, T.; Goldman, S.; Olson, R.K.; Byrne, B.; Coventry, W.L. Associations between selected dietary behaviours and academic achievement: A study of Australian school aged children. Appetite 2017, 116, 372-380. [CrossRef] [PubMed]

216. Faught, E.L.; Gleddie, D.; Storey, K.E.; Davison, C.M.; Veugelers, P.J. Healthy lifestyle behaviours are positively and independently associated with academic achievement: An analysis of self-reported data from a nationally representative sample of Canadian early adolescents. PLoS ONE 2017, 12, e0181938. [CrossRef] [PubMed]

217. Quach, J.; Nguyen, C.; O'Connor, M.; Wake, M. The cumulative effect of health adversities on children's later academic achievement. Acad. Pediatr. 2017, 17, 706-714. [CrossRef] [PubMed] 